\title{
In-Situ Laser Directed Energy Deposition of Biomedical Ti-Nb and Ti-Zr-Nb Alloys from Elemental Powders
}

\author{
Felipe Arias-González ${ }^{1}$, Alejandra Rodríguez-Contreras ${ }^{2,3,4} \mathbb{D}$, Miquel Punset ${ }^{2,3,4,5}{ }^{(D}$, José María Manero ${ }^{2,3,4}$,
} Óscar Barro ${ }^{6, *(\mathbb{D})}$, Mónica Fernández-Arias ${ }^{6}\left(\mathbb{D}\right.$, Fernando Lusquiños ${ }^{6,7}$, Francisco Javier Gil ${ }^{1}$ (D) and Juan Pou ${ }^{6,7}, * \mathbb{D}$

1 School of Dentistry, Universitat Internacional de Catalunya (UIC), 08195 Sant Cugat del Vallès, Spain; farias@uic.es (F.A.-G.); xavier.gil@uic.es (F.J.G.)

2 Biomaterials, Biomechanics and Tissue Engineering Group, Materials Science and Engineering Department, and Research Center for Biomedical Engineering, Technical University of Catalonia (UPC), 08019 Barcelona, Spain; alejandra.maria.rodriguez@upc.edu (A.R.-C.); miquel.punset@upc.edu (M.P.); jose.maria.manero@upc.edu (J.M.M.)

3 Institut de Recerca Sant Joan de Déu (IRSJD), 08034 Barcelona, Spain

4 Barcelona Research Center in Multiscale Science and Engineering, Universitat Politècnica de Catalunya (UPC), 08019 Barcelona, Spain

5 UPC Innovation and Technology Center (CIT-UPC), Universitat Politècnica de Catalunya (UPC), 08034 Barcelona, Spain

6 LaserOn Research Group, CINTECX, School of Engineering, Universidade de Vigo (UVIGO), Lagoas Marcosende, 36310 Vigo, Spain; monfernandez@uvigo.es (M.F.-A.); flusqui@uvigo.es (F.L.)

check for updates

Citation: Arias-González, F.; Rodríguez-Contreras, A.; Punset, M.; Manero, J.M.; Barro, Ó.; FernándezArias, M.; Lusquiños, F.; Gil, F.J.; Pou, J. In-Situ Laser Directed Energy Deposition of Biomedical Ti-Nb and Ti-Zr-Nb Alloys from Elemental Powders. Metals 2021, 11, 1205. https://doi.org/10.3390/ met11081205

Academic Editor: Joel Andersson

Received: 11 June 2021

Accepted: 26 July 2021

Published: 28 July 2021

Publisher's Note: MDPI stays neutral with regard to jurisdictional claims in published maps and institutional affiliations.

Copyright: (c) 2021 by the authors. Licensee MDPI, Basel, Switzerland. This article is an open access article distributed under the terms and conditions of the Creative Commons Attribution (CC BY) license (https:// creativecommons.org/licenses/by/ $4.0 /)$.
7 Galicia Sur Health Research Institute (IIS Galicia Sur), SERGAS-Universidade de Vigo (UVIGO), 36312 Vigo, Spain

* Correspondence: obarro@uvigo.es (Ó.B.); jpou@uvigo.es (J.P.); Tel.: +34-986-812-216 (J.P.)

Abstract: In order to achieve the required properties of titanium implants, more resources and research are needed to turn into reality the dream of developing the perfect implant material. The objective of this study was to evaluate the viability of the Laser Directed Energy Deposition to produce biomedical $\mathrm{Ti}-\mathrm{Nb}$ and $\mathrm{Ti}-\mathrm{Zr}-\mathrm{Nb}$ alloys from elemental powders ( $\mathrm{Ti}, \mathrm{Nb}$ and $\mathrm{Zr}$ ). The Laser Directed Energy Deposition is an additive manufacturing process used to build a component by delivering energy and material simultaneously. The material is supplied in the form of particles or wire and a laser beam is employed to melt material that is selectively deposited on a specified surface, where it solidifies. Samples with different compositions are characterized to analyze their morphology, microstructure, constituent phases, mechanical properties, corrosion resistance and cytocompatibility. Laser-deposited Ti-Nb and Ti-Zr-Nb alloys show no relevant defects, such as pores or cracks. Titanium alloys with lower elastic modulus and a significantly higher hardness than $\mathrm{Ti}$ grade 2 were generated, therefore a better wear resistance could be expected from them. Moreover, their corrosion resistance is excellent due to the formation of a stable passive protective oxide film on the surface of the material; in addition, they also possess outstanding cytocompatibility.

Keywords: Laser Directed Energy Deposition (LDED); titanium alloys; microstructure; young's modulus; corrosion resistance; cytocompatibility

\section{Introduction}

Metals and their alloys are widely used as biomedical materials and it is estimated that $70-80 \%$ of biomedical implants are made of metallic materials [1]. Commercially pure titanium (cp-Ti) and Ti-6Al-4V have stood the test of time and are the most commonly used metallic materials in various orthopedic and dental applications [2]. They possess many fascinating properties, such as toughness, strong corrosion resistance, excellent biocompatibility, and a relatively low elastic modulus in comparison to other metallic materials [3].

Nevertheless, cp-Ti and Ti-6Al-4V present some drawbacks. The mechanical properties of $\mathrm{cp}$-Ti cannot satisfy the requirements of biomaterials in some cases where high strength 
is necessary, such as hard tissue replacement, or under intensive wear and use [1]. Ti$6 \mathrm{Al}-4 \mathrm{~V}$ possesses ideal mechanical properties but the diffusion of cytotoxic $\mathrm{V}$ and $\mathrm{Al}$ ions may cause long-term health issues once released inside human body [1-4]. Moreover, the elastic modulus of cp-Ti (105 GPa) and Ti-6Al-4V (110-115 GPa) are still greater than that of cortical bone (10-30 GPa) [1-4]. If the implant exhibits a higher elastic modulus than the surrounding bone, a phenomenon known as stress shielding can occur [1-5]. Applied stresses are taken up by the implant rather than by the bone, hence hindering bone regeneration while enhancing bone resorption. The resorption of the bone by the body may in turn lead to complications such as bone fracture and the loosening of the implant [1-5].

Recently, significant thrust has been generated towards the development of new biomedical titanium alloys elaborated from a combination of elements with good biocompatibility and low toxicity, such as $\mathrm{Nb}, \mathrm{Ta}, \mathrm{Zr}, \mathrm{Sn}$, and $\mathrm{Hf}[1-5]$. Among them, $\beta$-type Ti alloys have been considered to have the lowest elastic modulus in combination with a high strength, good corrosion resistance, and excellent biocompatibility [6]. In general, $\beta$-type Ti alloys retain close to $100 \mathrm{vol} \%$ of BCC $\beta$-phase when quenched from the single $\beta$-phase field to room temperature. This is accomplished by alloying Ti with sufficient quantities of $\beta$-stabilizing elements (e.g., $\mathrm{Nb}$ or $\mathrm{Ta}$ ) to suppress the formation of other phases [6]. To date, many low modulus $\beta$-type Ti alloys have been developed for biomedical applications, such as Ti-Nb [7,8], Ti-Ta [8,9], Ti-Nb-Zr [10-15], Ti-Ta-Zr [16,17], Ti-Nb-Hf [18,19], Ti-Nb-Ta-Zr [20-24], Ti-Nb-Sn [25-27], Ti-Nb-Zr-Sn [28,29], etc.

Laser Directed Energy Deposition (LDED) is an additive manufacturing (AM) process to build a component by delivering energy and material simultaneously [30]. The material is supplied in the form of particles or wire and a laser beam is employed to melt material that is selectively deposited on a specified surface, where it solidifies. LDED can be employed to process any material that can be melted, such as metals and some ceramics $[31,32]$. This technology is particularly suitable for producing low volumes of near net-shape products [33].

LDED has been previously employed to generate pieces of titanium and titanium alloys such as thin walls of cp-Ti [34], porous Ti structures for load bearing implants [35,36], Ti-6Al-4V scaffolds for patient-specific bone tissue engineering [37], or a biocompatible $\beta$-type Ti alloy, Ti-27.5Nb (at\%) [38]. High cooling rates are achieved during this process, so the metastable $\beta$-phase is retained when some $\beta$-type Ti alloy parts are manufactured by LDED. As a result, laser-deposited $\beta$-type Ti alloys, such as Ti-27.5Nb (at \%), present an elastic modulus similar to that of a solution-treated material followed by water quenching [38].

Since Laser Directed Energy Deposition can deliver feedstock material in the form of particles, it allows the flexibility to deposit blends of elemental powders to produce custom alloy components in situ. LDED with elemental powders as feedstock materials has been used to generate in-situ biomedical $\beta$-type Ti alloys, such as Ti-35Nb-7Zr-5Ta (wt\%) [39-41] and Ti-26Nb (at\%) [42]. However, the in-situ Laser Directed Energy Deposition of these alloys is a challenge because of the relatively high melting points of $\mathrm{Nb}(2750 \mathrm{~K})$ and $\mathrm{Ta}$ ( $3290 \mathrm{~K})$. These high melting points have to be exceeded to completely melt the $\mathrm{Nb}$ or $\mathrm{Ta}$ particles, and thus avoid compositional inhomogeneity [39,42].

In order to achieve the required properties of titanium implants, more resources and research are needed to turn into reality the dream of developing an implant material which is tough, biocompatible, corrosion, and wear resistant, with elastic modulus close to that of bone [2]. In this work, the advantages provided by the Laser Directed Energy Deposition are exploited to generate different alloys elaborated from a combination of elemental powders ( $\mathrm{Ti}, \mathrm{Nb}$ and $\mathrm{Zr}$ ) in situ. The feasibility of the technique to produce biomedical Ti$\mathrm{Nb}$ and Ti-Zr-Nb alloys ranging from $0 \mathrm{wt} \% \mathrm{Zr}$ to $35 \mathrm{wt} \% \mathrm{Zr}$ from elemental powders was examined. Samples with different compositions are characterized to evaluate and compare their performance. The morphology and microstructure of the samples was studied by optical microscopy (OM, Olympus SZX16, Olympus, Tokyo, Japan); elemental composition and its homogeneity was studied by scanning electron microscopy (SEM, Phenom XL, 
Thermo Fisher Scientific, Waltham, MA, USA) and energy-dispersive X-ray spectroscopy (EDS, Phenom XL, Thermo Fisher Scientific, Waltham, MA, USA); and constituent phases were determined by X-ray diffraction (XRD, Bruker D8 Advance, Bruker, Billerica, MA, USA). The hardness, elastic modulus and some ratios related with the wear resistance and service life of a component were analyzed by means of nanoindentation. Corrosion behavior was tested via potentiodynamic polarization technique. Finally, in vitro cell culture experiments were carried out to assess the cytocompatibility.

\section{Materials and Methods}

\subsection{Samples Generation by Laser Directed Energy Deposition (LDED)}

Laser Directed Energy Deposition (LDED) with elemental powders ( $\mathrm{Ti}, \mathrm{Nb}$ and $\mathrm{Zr}$ ) as feedstock materials was employed to produce in-situ $\mathrm{Ti}-\mathrm{Nb}$ and $\mathrm{Ti}-\mathrm{Zr}-\mathrm{Nb}$ samples with different compositions. Figure 1 shows a scheme of the LDED experimental set-up. The experiments were performed employing a high-power diode laser from DILAS (Mainz, Germany) with a wavelength between 915 and $976 \mathrm{~nm}$ and a maximum output power of $1600 \mathrm{~W}$. The laser beam was focused on the substrate by a lens with a diameter of $50 \mathrm{~mm}$ and a focal length of $250 \mathrm{~mm}$, obtaining a circular spot with a diameter of approximately $3 \mathrm{~mm}$ on the surface of the substrate. The samples were generated with a delivered laser powder of $1000 \mathrm{~W}$, in continuous mode, obtaining a mean irradiance of $141.5 \mathrm{~W} / \mathrm{mm}^{2}$.

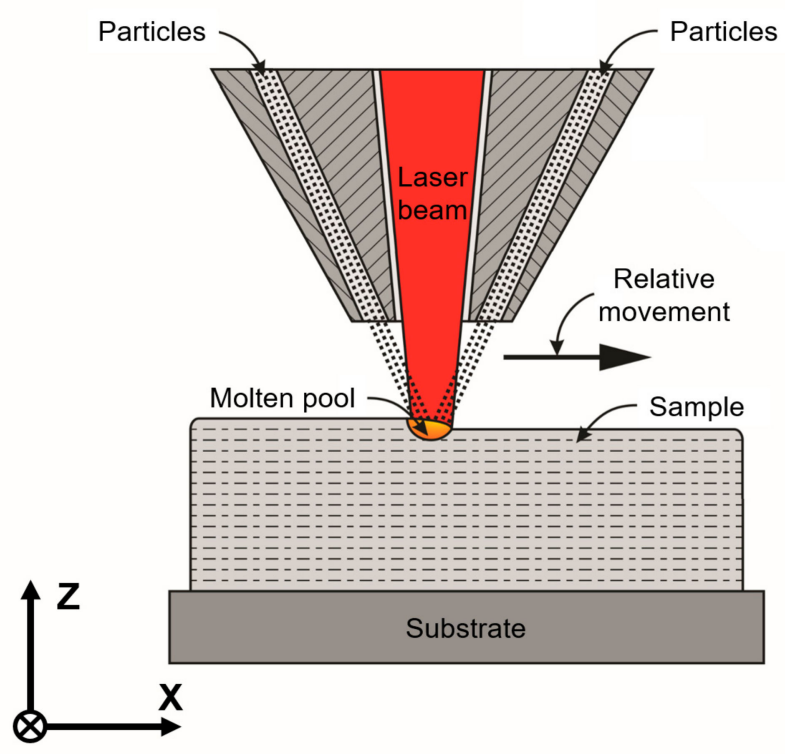

Figure 1. Scheme of Laser Directed Energy Deposition (LDED) experimental set-up.

The samples were generated on flat $\mathrm{cp}$-Ti grade 2 substrates with dimensions of $50 \mathrm{~mm} \times 100 \mathrm{~mm} \times 10 \mathrm{~mm}$. A computer numerically controlled (CNC) table was employed to move the substrate with regard to the laser head at $6 \mathrm{~mm} / \mathrm{s}$ to generate the first layer with a longitude of $40 \mathrm{~mm}$. When it reached the end, the substrate was moved down one step, starting the movement in the opposite direction to create a new overlaid layer. This sequence of movements was performed continuously in a loop and a part of several millimeters in height was built, layer by layer. The samples were generated by depositing up to 100 layers continuously with a step between layers of $0.25 \pm 0.02 \mathrm{~mm}$.

Pure Ti, $\mathrm{Nb}$, and $\mathrm{Zr}$ elemental powders were used as a feedstock material to generate the samples. The characteristics of the powders selected as feedstock material are presented in Table 1. As can be seen in Figure 2, the different powders have irregular shapes, and its size range is different for each element. The powders were carried by argon and coaxially injected in the molten pool by a coaxial laser head. The mass flow was fixed at a rate of $3 \mathrm{~g} / \mathrm{min}$. The feedstock material was melted and distributed layer by layer over the partly-built sample. This molten material immediately solidified, transmitting the heat 
mainly by conduction to the substrate when the laser beam went on sweeping a path, leaving the interaction zone. The whole process was carried out in a controlled atmosphere, inside a chamber with a low oxygen content $\left(\mathrm{O}_{2}<50 \mathrm{ppm}\right)$ to avoid the oxidation in the molten pool.

Table 1. Characteristics of pure elemental $\mathrm{Ti}, \mathrm{Nb}$, and $\mathrm{Zr}$ powders used as feedstock material to produce the laser-deposited samples.

\begin{tabular}{ccccc}
\hline Material & Purity & Powder size & Morphology & Supplier \\
\hline $\mathrm{Ti}$ & $>99.8 \%$ & $90-125 \mu \mathrm{m}$ & Angular/Blocky & Oerlikon \\
$\mathrm{Nb}$ & $>99.8 \%$ & $0-44 \mu \mathrm{m}$ & Angular/Blocky & Alfa Aesar \\
$\mathrm{Zr}$ & $>99.8 \%$ & $44-105 \mu \mathrm{m}$ & Angular/Blocky & Materion \\
\hline
\end{tabular}

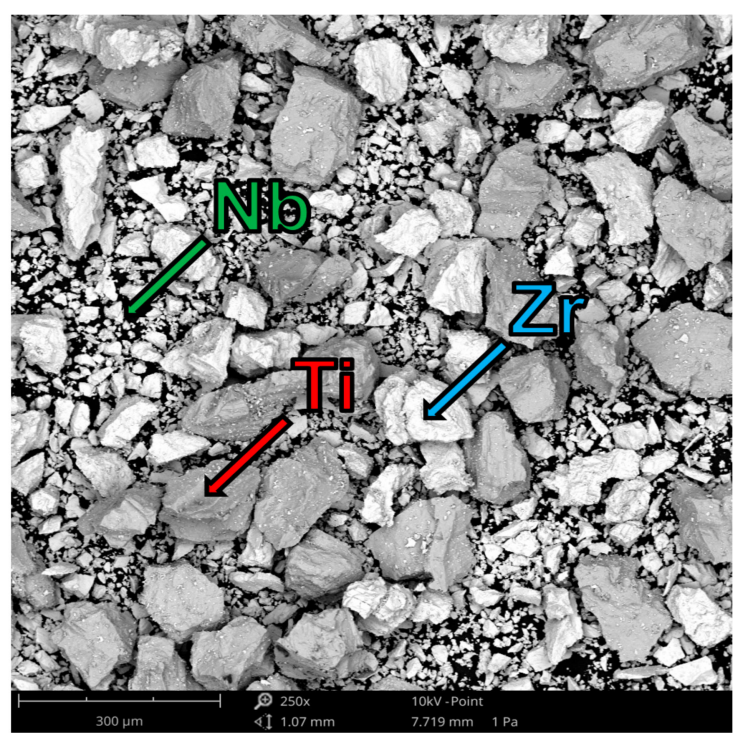

Figure 2. SEM micrograph showing particle size and morphology of $\mathrm{Ti}, \mathrm{Nb}$, and $\mathrm{Zr}$ elemental powders employed as feedstock material to produce the laser-deposited samples.

\subsection{Morphological and Microstructural Characterization}

The samples were cut, embedded in epoxy resin, and polished in order to examine the longitudinal section (XZ) and the transverse section (YZ). The morphology and microstructure were analyzed by optical microscopy (OM, Olympus SZX16, Olympus, Tokyo, Japan) after etching the samples with Kroll's reagent. Elemental composition of one sample of each material and its homogeneity was studied by means of scanning electron microscopy (SEM, Phenom XL, Thermo Fisher Scientific, Waltham, MA, USA) and energy-dispersive X-ray spectroscopy (EDS, Thermo Fisher Scientific Phenom XL, Waltham, MA, USA). X-ray diffraction (XRD, Bruker D8 Advance, Bruker, Billerica, MA, USA) analysis was carried out using monochromated $\mathrm{Cu}-\mathrm{K} \alpha$ radiation $\left(\lambda=1.54 \AA\right.$ ) over the $20-100^{\circ} 2 \theta$ range with a step size of $0.02^{\circ}$. Diffractograms were obtained directly from the polished surface of the longitudinal section (XZ) to identify the constituent phases of each sample. The estimated X-ray beam spot diameter and beam penetration depth were between $8-10 \mathrm{~mm}$ and between 20-30 $\mu \mathrm{m}$, respectively.

\subsection{Mechanical Characterization}

Elastic modulus and hardness were examined via nanoindentation using a Berkovich indenter tip and continuous stiffness measurement (CSM) technique on an MTS nanoindenter XP (MTS Nano Instruments, Oak Ridge, TN, USA). A maximum indentation depth of $1000 \mathrm{~nm}$ was set. In this technique, the mechanical properties are obtained by applying a small oscillating force to the indenter and measuring the amplitude and phase shift of 
the oscillations that result. This allows the hardness and elastic modulus of the material to be obtained continuously throughout the indentation process in a certain indentation depth range. This range is chosen based on the stability of the values as a function of depth. Average elastic modulus and hardness were obtained from a large number of indentations, 21 indentations arranged in a 3 row and 7 column matrix were programmed for one sample of each material. However, very often topographic defects at the micrometer level can lead to an invalid indentation, and the height differences in the sample itself can cause an invalid result because the nanoindenter fails to detect the surface correctly when the tip is approaching. For practical purposes, those unsuccessful indentations that produced invalid outcomes were rejected.

\subsection{Electrochemical Characterization}

Electrochemical measurements were carried out using a Hewlett Packard potentiostat in a standard three electrode setup containing a saturated calomel electrode (SCE) as the reference electrode, a platinum electrode as cathode, and one sample of each material $\left(2 \pm 0.02 \mathrm{~cm}^{2}\right.$ exposed area) as a working electrode. Experiments were performed in phosphate buffered saline (PBS) at $37.0 \pm 0.5^{\circ} \mathrm{C}$. Samples were prepared by epoxy cold resin mounting, followed by mechanical polishing with $\mathrm{SiC}$ abrasive paper up to a grit size of P1200, and ultrasonically cleaned before their immersion into the electrolyte solution. Upon immersion, the open-circuit potential $\left(\mathrm{E}_{\mathrm{ocp}}\right)$ was measured for $2 \mathrm{~h}$ and the data were recorded each second. Subsequently, potentiodynamic polarization scans were performed, incrementing the voltage from $\mathrm{E}_{\mathrm{ocp}}-0.15 \mathrm{~V}$ to $1.5 \mathrm{~V}$ at a scan rate of $1 \mathrm{mV} / \mathrm{s}$ (according to ISO 10271:2011). After that, the voltage was reversed back.

\subsection{Cytocompatibility Assessing}

\subsubsection{Cell Culture}

Human osteosarcoma SaOS-2 cells (ATCC HTB-85, Manassas, VA, USA) at passage 13-14 were cultured in McCoy's 5A medium (Sigma-Aldrich, St. Louis, MO, USA), supplemented with 10\% fetal bovine serum (FBS) and 1\% penicillin/streptomycin antibiotics (50 U/mL and $50 \mu \mathrm{g} / \mathrm{mL}$, respectively) at $37^{\circ} \mathrm{C}$ in a humidified atmosphere and $5 \%(v / v)$ $\mathrm{CO}_{2}$. A cellular density of 10000 cells/well were cultured on the different Ti alloy surfaces (2 samples of each material) in Falcon 12-well plates for $24 \mathrm{~h}$. The samples were previously sterilized by washing them 3 times with 100\% ethanol for 5 min each and were left under UV for $30 \mathrm{~min}$. After $24 \mathrm{~h}$, cells were fixed with paraformaldehyde (PFA) $4 \%$ in PBS for $30 \mathrm{~min}$ at $4{ }^{\circ} \mathrm{C}$. Afterwards, the samples were washed thrice (5 min each) with phosphate-buffered saline (PBS, pH 7.2-7.4) and kept at $4{ }^{\circ} \mathrm{C}$ for analyzing.

\subsubsection{Cell Analyses}

Samples with osteoblasts-like cells were processed for immunofluorescence labeling to visualize actin filaments, vinculin, and nuclei. The cells were permeabilized by exposure to a $0.05 \%$ solution of Triton X-100 in PBS for $20 \mathrm{~min}$. After washing the samples (three times, $5 \mathrm{~min}$ each) using a PBS solution with glycine (20 mM) (PBS-Gly), bovine serum albumin (BSA) 1\% solution in PBS was added as the blocking solution for $30 \mathrm{~min}$. The antibody mouse anti-vinculin (1:100, Monoclonal Anti-Vinculin Clone hVIN-1, SigmaAldrich, St. Louis, MO, USA) was used for the stain of the focal adhesions. Then, the secondary antibodies, anti-mouse Alexa 488 (1:2000, Thermo Fisher Scientific, Waltham, MA, USA), together with phalloidin-rodhamine (1:300, Thermo Fisher), were used for the green fluorescence for vinculin labeling and red fluorescence for actin labeling, respectively. Antibodies were diluted in a $0.05 \%$ triton solution in PBS and were incubated in the dark for $1 \mathrm{~h}$ at room temperature. Between each incubation step, the samples were washed (3 times with PBS-Gly for 5 min each). Finally, 4',6-diamidino-2-phenylindole (DAPI) (1:1000, Molecular Probes, Thermo Fisher Scientific) solution diluted in PBS-Gly was used to make nuclei blue-fluorescent. After incubation for $2 \mathrm{~min}$ in the dark, the samples were washed ( 3 times with PBS-Gly for 5 min each). The samples were stored in the dark at $4{ }^{\circ} \mathrm{C}$. 
Samples were then examined under a Zeiss LSM 800 microscope (Zeiss Group, Oberkochen, Germany). For quantitative cell counting, ten microscope fields under the $10 \times$ objective were selected at random from the surfaces of the materials. For the estimation of the cell area and the size of focal adhesions (FA), immunofluorescence images were captured under $63 \times$ objective. Images were analyzed using ImageJ software.

\subsubsection{Cell Preparation for SEM Observation}

Cells on cp-Ti grade 2 and the Ti-Nb and Ti-Zr-Nb alloys were fixed with paraformaldehyde (PFA) $4 \%$ in PBS ( $30 \mathrm{~min}$ at $4{ }^{\circ} \mathrm{C}$ ), and washed 3 times (5 min each) with PBS. The cells were then dehydrated by exposure to a graded sequence of aqueous ethanol $(30-100 \%)$ and dried at room temperature for $24 \mathrm{~h}$. Cell morphology was analyzed by scanning electron microscopy (SEM).

\section{Results and Discussion}

The in-situ Laser Directed Energy Deposition of Ti-Nb and Ti-Zr-Nb alloys elaborated from a combination of elemental powders is a challenge due to the different melting points of $\mathrm{Ti}(1941 \mathrm{~K}), \mathrm{Zr}(2128 \mathrm{~K})$, and $\mathrm{Nb}(2750 \mathrm{~K})$. The high melting point of $\mathrm{Nb}$ has to be exceeded in the molten pool in order to guarantee the complete melting of the $\mathrm{Nb}$ particles, however it is also crucial to not surpass the boiling point of $\mathrm{Ti}(3560 \mathrm{~K})$. In this work, $\mathrm{Nb}$ particles with a size smaller than the $\mathrm{Ti}$ and $\mathrm{Zr}$ particles were employed to facilitate their complete melting and diffusion in the molten pool. The morphology, size, and characteristics of the elemental powders selected as feedstock material are summarized in Table 1 and Figure 2.

The feasibility of the LDED to produce Ti- $\mathrm{Nb}$ and Ti- $\mathrm{Zr}-\mathrm{Nb}$ alloys from elemental powders was examined. An optical micrograph showing the cross section (YZ) of a sample still attached to the substrate is presented as an example in Figure 3. The samples show no pores or cracks. A more detailed analysis has been done by means of scanning electron microscopy (SEM) all along the cross section (YZ) of the samples. SEM micrographs of $\mathrm{Ti}-\mathrm{Nb}$ and Ti-Zr-Nb samples are presented as examples in Figures 4 and 5, respectively. Three micrographs are shown for each group of materials. They were obtained at the three different representative locations remarked in Figure 3: central area (A), mid-height side area (B), and side area at the base (C). Unmelted or partially-melted $\mathrm{Nb}$ particles were found in all the samples, though only in the side area at the base (Figures $4 \mathrm{c}$ and $5 \mathrm{c}$ ).

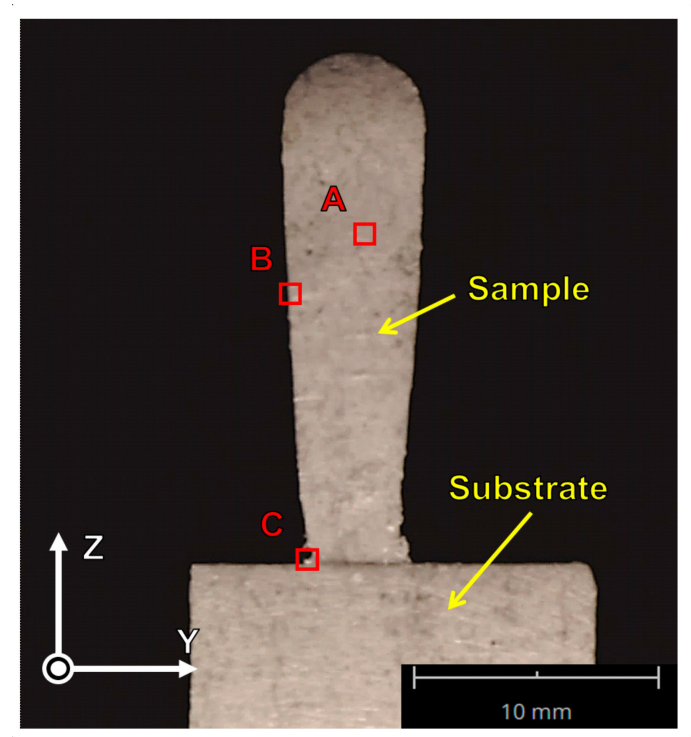

Figure 3. Optical micrograph showing the cross section $(Y Z)$ of a sample still attached to the substrate. Three representative areas are remarked: central area (A), mid-height side area (B), and side area at the base $(C)$. 


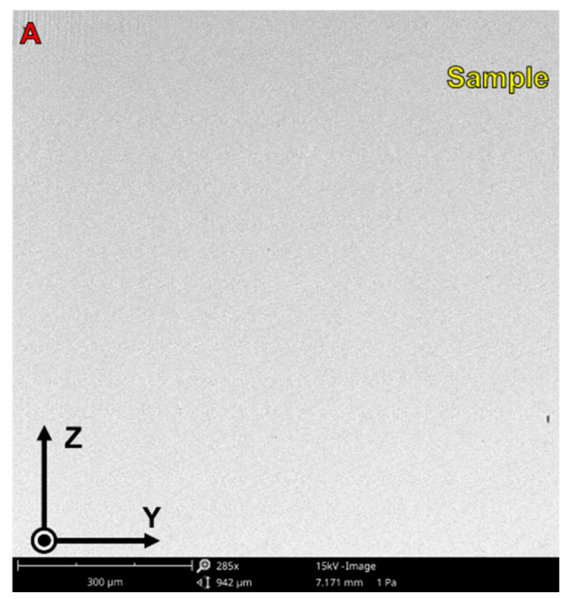

(a)

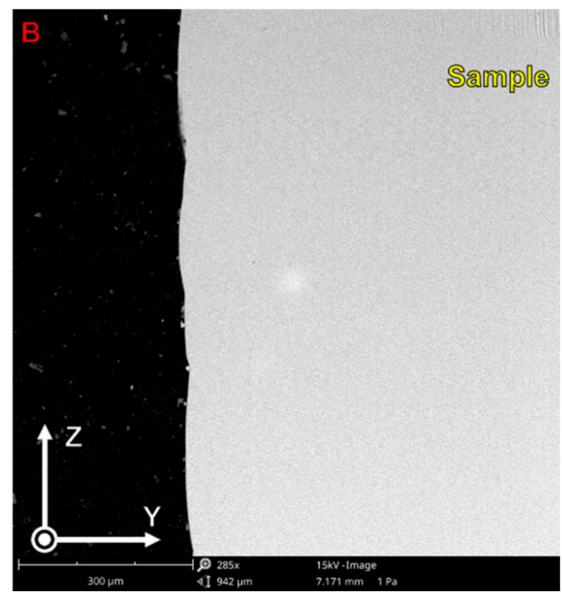

(b)

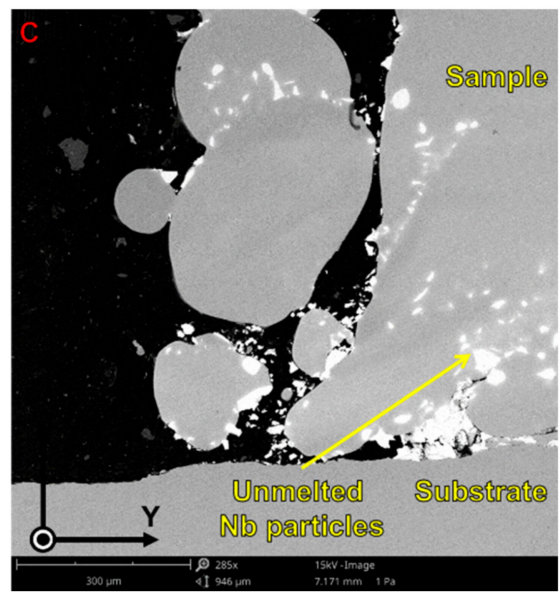

(c)

Figure 4. SEM micrographs of Ti-Nb samples obtained at three different locations: (a) central area, (b) mid-height side area, and (c) side area at the base.

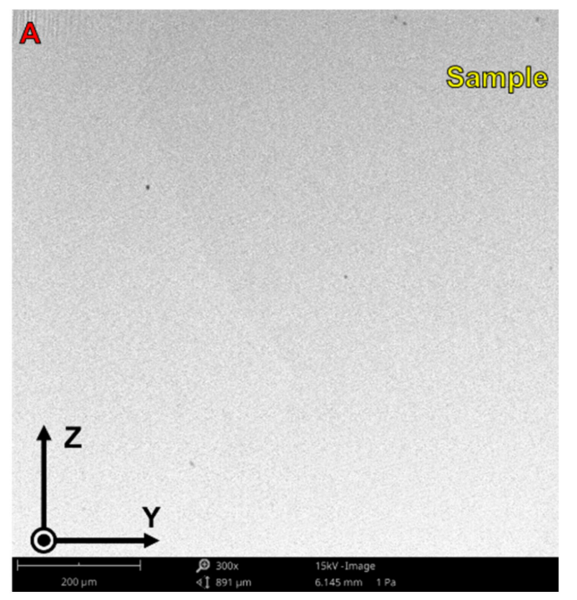

(a)

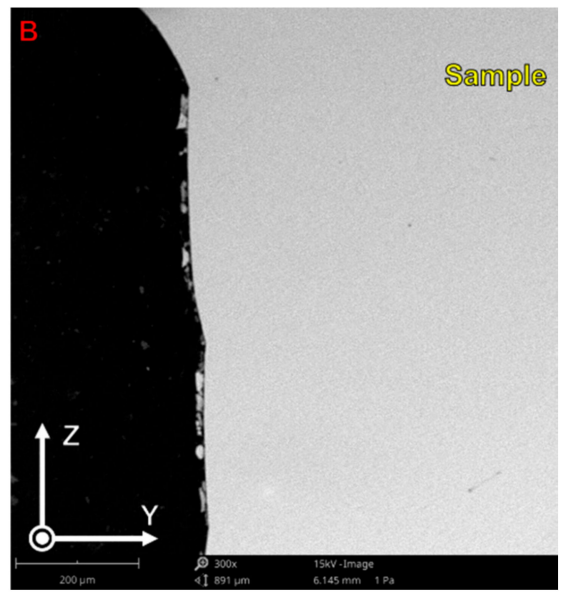

(b)

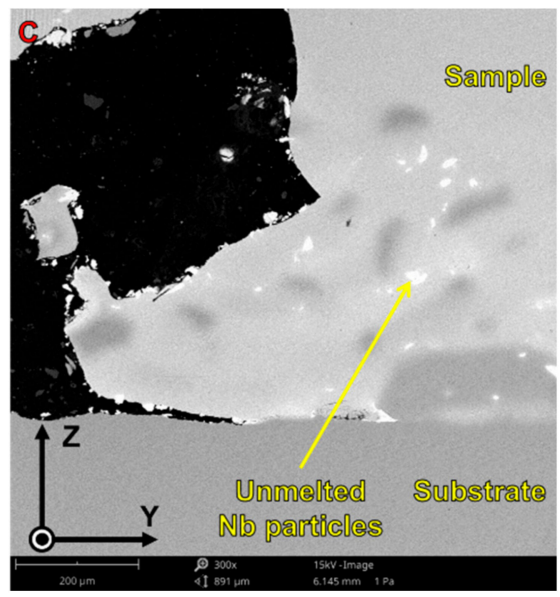

(c)

Figure 5. SEM micrographs of Ti-Zr-Nb samples obtained at three different locations: (a) central area, (b) mid-height side area, and (c) side area at the base.

The base of the piece is where the temperature reached during the process is lower and is not high enough to completely melt the $\mathrm{Nb}$ particles. The first layers of the piece were deposited starting at room temperature without preheating the substrate, and the laser irradiance on the external part of the spot was lower than in the middle. As the process went on and more layers are added, the substrate and previously deposited layers reached a higher temperature than the initial one. After depositing the first layers (above 1-2 mm), the temperature achieved at any point of the molten pool was high enough to completely melt the $\mathrm{Nb}$ particles. The presence of unmelted or partially-melted $\mathrm{Nb}$ particles at the base of the component did not have an impact on its performance because these first layers of material are sacrificial and must be removed when the final component is taken away from the substrate. Moreover, if necessary, this effect could be avoided by preheating the substrate or increasing laser irradiance when the first layers are deposited.

The microstructure was examined on the longitudinal section (XZ) of the samples by optical microscopy after polishing and etching with Kroll's reagent. Figure 6 shows the microstructure in the longitudinal section $(X Z)$ of a laser-deposited specimen selected as an example. The microstructure consists of large, elongated columnar prior $\beta$ grains that grow in parallel to the building direction, except in the upper part of the piece, where equiaxed grains are formed. This microstructure is commonly observed in laser- 
deposited titanium alloys $[30,34,37,39,42]$ and its formation mechanism has been explained in previous studies [30,34].

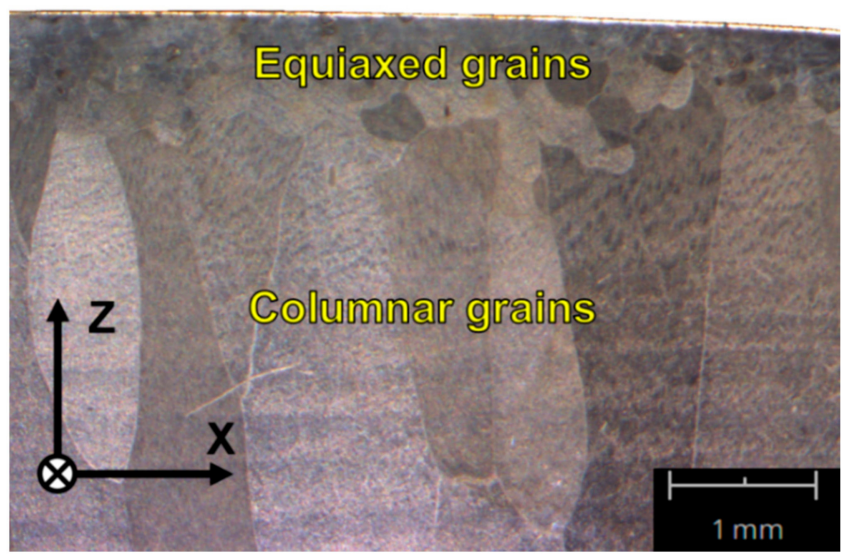

Figure 6. Optical micrograph showing microstructure in the longitudinal section (XZ) of a sample. It consists of elongated columnar prior $\beta$ grains that grow in parallel to the building direction, except in the upper part of the piece, where equiaxed grains are formed.

The elemental composition of the laser-deposited alloys was determined from energydispersive X-ray spectroscopy (EDS) studies. EDS was performed on five areas at different heights for each material to obtain an average composition and its dispersion. The overall composition of each material is presented in Table 2 (in wt $\% \pm$ SD) and Table 3 (in at $\% \pm \mathrm{SD}$ ). Standard deviation is a measure of the dispersion in the composition at the different areas, so it is an indicator of the homogeneity in the composition of the samples. Since the highest standard deviation was $1.5 \mathrm{wt} \%$, their elemental composition can be considered homogenous, especially when it is taken into account that the error associated with the measurement of compositions via EDS is typically $1-2 \%$.

Table 2. Semi-quantitative elemental composition measured by EDS ( $w \mathrm{t} \% \pm \mathrm{SD}$ ) and molybdenum equivalence (Moeq) calculated from the Equation (1) proposed by Mehjabeen [43].

\begin{tabular}{|c|c|c|c|c|c|}
\hline Material & Alloy & $\mathrm{Ti}(w t \% \pm \mathrm{SD})$ & $\mathrm{Nb}(w \mathrm{t} \% \pm \mathrm{SD})$ & $\mathrm{Zr}(w \mathrm{w} \% \pm \mathrm{SD})$ & $\mathrm{Mo}_{\mathrm{eq}}(w \mathrm{t} \% \pm \mathrm{SD})$ \\
\hline 1 & $\mathrm{Ti}-12 \mathrm{Nb}$ & Bal. & $12.4 \pm 1.1$ & - & $3.9 \pm 0.3$ \\
\hline 2 & $\mathrm{Ti}-37 \mathrm{Nb}$ & Bal. & $36.9 \pm 1.4$ & - & $9.7 \pm 0.4$ \\
\hline 3 & $\mathrm{Ti}-57 \mathrm{Nb}$ & Bal. & $57.2 \pm 1.1$ & - & $14.6 \pm 0.4$ \\
\hline 4 & Ti-34Zr-15Nb & Bal. & $14.8 \pm 1.4$ & $33.9 \pm 1.2$ & $8.2 \pm 0.4$ \\
\hline 5 & $\mathrm{Ti}-35 \mathrm{Zr}-25 \mathrm{Nb}$ & Bal. & $25.1 \pm 1.5$ & $35.2 \pm 0.5$ & $10.8 \pm 0.5$ \\
\hline
\end{tabular}

Table 3. Semi-quantitative elemental composition measured by EDS (at $\% \pm \mathrm{SD}$ ) and electron to atom ratio (e/A ratio) calculated from the Equation (2).

\begin{tabular}{|c|c|c|c|c|c|}
\hline Material & Alloy & $\mathrm{Ti}($ at $\% \pm \mathrm{SD})$ & $\mathrm{Nb}(\mathrm{at} \% \pm \mathrm{SD})$ & $\mathrm{Zr}(\mathrm{at} \% \pm \mathrm{SD})$ & e/A ratio \\
\hline 1 & $\mathrm{Ti}-12 \mathrm{Nb}$ & Bal. & $6.8 \pm 0.6$ & - & $4.068 \pm 0.006$ \\
\hline 2 & $\mathrm{Ti}-37 \mathrm{Nb}$ & Bal. & $23.1 \pm 1.1$ & - & $4.231 \pm 0.011$ \\
\hline 3 & $\mathrm{Ti}-57 \mathrm{Nb}$ & Bal. & $40.8 \pm 1.1$ & - & $4.408 \pm 0.011$ \\
\hline 4 & $\mathrm{Ti}-34 \mathrm{Zr}-15 \mathrm{Nb}$ & Bal. & $10.0 \pm 1.1$ & $23.3 \pm 1.2$ & $4.100 \pm 0.011$ \\
\hline 5 & Ti-35Zr-25Nb & Bal. & $18.2 \pm 1.3$ & $26.0 \pm 0.2$ & $4.182 \pm 0.013$ \\
\hline
\end{tabular}

A well-known and useful parameter for characterizing any titanium alloy composition is the molybdenum equivalency $\left(\mathrm{Mo}_{\mathrm{eq}}\right)[6,15]$. The $\mathrm{Mo}_{\mathrm{eq}}$ is an empirical parameter representing the contribution of alloying elements on the stability of BCC $\beta$-phase in comparison to that of Mo [15]. Although $\mathrm{Mo}_{\text {eq }}$ has been commonly used as a guideline, there have been some controversial issues concerning the effect of $\mathrm{Zr}$ as a $\beta$-stabilizer [15,43-45]. 
$\mathrm{Zr}$ has been considered to have a neutral effect on the phase stability, but it behaves as a weaker $\beta$-stabilizing element in Ti-Zr-Nb alloys $[15,43-45]$. In order to properly address the $\beta$-stabilizing effect of $\mathrm{Zr}$ in Ti-Zr-Nb alloys, Equation (1) was proposed by Mehjabeen et al. [43]. When $\mathrm{Mo}_{\text {eq }}$ is close to or above $10 \mathrm{wt} \%$, the alloy contains $\beta$-phase as the primary phase after water quenching [43]. In the present work, Moeq is calculated from Equation (1) for each alloy composition and the results are presented in Table 2.

$$
\mathrm{Mo}_{\mathrm{eq}}=0.97+0.238 \cdot \mathrm{Nb}(\mathrm{wt} \%)+0.11 \cdot \mathrm{Zr}(\mathrm{wt} \%)
$$

An alternative parameter to characterize the BCC $\beta$-phase stability in titanium alloys is the average number of valence electrons per atom or electron to atom ratio (e/A ratio) $[6,15]$. It has been reported that, as the value of e/A ratio decreases, the shear modulus $\mathrm{C}^{\prime}=\left(\mathrm{C}_{11}-\mathrm{C}_{12}\right) / 2$ and bulk modulus $\mathrm{B}$ of a BCC crystal also decrease, causing the $\beta$-phase to become unstable $[6,15]$. Moreover, the e/A ratio is a dominant factor governing the elastic constants of $\beta$-type titanium alloys and there is a clear tendency of decreasing elastic modulus with decreasing e/A ratio [15]. The e/A ratio is calculated from Equation (2):

$$
\mathrm{e} / \mathrm{A} \text { ratio }=4 \cdot \operatorname{Ti}(\mathrm{at} \%)+4 \cdot \mathrm{Zr}(\mathrm{at} \%)+5 \cdot \mathrm{Nb}(\mathrm{at} \%)=4+\mathrm{Nb}(\mathrm{at} \%)
$$

where the coefficients are the valence electrons of each element present in the alloy. The simplified version of the equation highlights that the $\mathrm{Ti}-\mathrm{Nb}$ and $\mathrm{Ti}-\mathrm{Zr}-\mathrm{Nb}$ alloys have a minimum e/A ratio of four that increases with $\mathrm{Nb}(\mathrm{at} \%)$. The e/A ratio has been calculated for each alloy composition and the results are presented in Table 3.

XRD analysis was performed to determine the constituent phases of the materials (see Figure 7). A sample of cp-Ti grade 2, the material employed as substrate, was introduced as a control and was named material 0 . Material 0 is formed by HCP $\alpha$-phase equiaxed grains, which are relatively fine, and its diffraction pattern agrees with that expected from an ideal powder or reference patterns [34,46-48]. However, the diffraction patterns of laser deposited-materials (from material 1 to material 5) present variations in the relative intensity of their peaks, and some peaks are missed in comparison to the patterns reported in literature $[34,46,47,49,50]$. These variations are attributed to the coarse microstructure of the laser-deposited materials that consist of large, elongated prior $\beta$ grains (see Figure 6), so the area analyzed by XRD does not contain a smooth distribution of crystals with random orientations. Despite this, it is possible to clearly identify the constituent phases for all the materials, as it is indicated in their respective diffractograms in Figure 7.

Figure 8 displays a diagram that has been created in order to summarize and understand the relationship between elemental composition, $\mathrm{Mo}_{\mathrm{eq}}, \mathrm{e} / \mathrm{A}$ ratio, and constituent phases. Laser-deposited materials with an Mo $\mathrm{M}_{\text {eq }}$ above $10 \mathrm{wt} \%$ consist of a single BCC $\beta$-phase (materials 3 and 5). When $\mathrm{Mo}_{\text {eq }}$ is below $10 \mathrm{wt} \%$, laser-deposited materials do not completely retain $100 \mathrm{vol} \% \beta$-phase, so the orthorhombic martensite $\alpha$ " -phase is also detected in materials 2 and 4, while material 1 is formed only by HCP $\alpha$-phase. Therefore, $\mathrm{Mo}_{\text {eq }}>10 \mathrm{wt} \%$ can be considered a suitable guideline to predict the stability of $\beta$-phase in $\mathrm{Ti}-\mathrm{Nb}$ and $\mathrm{Ti}-\mathrm{Zr}-\mathrm{Nb}$ laser-deposited components in the as-built state.

The electron to atom ratio (e/A ratio) has some flaws when it comes to estimating the constituent phases in Ti-Zr-Nb laser-deposited materials. A higher e/A ratio does not imply a higher stability of the BCC $\beta$-phase. For example, material $2(\mathrm{e} / \mathrm{A}=4.231 \pm 0.011)$ presents a higher e/ $\mathrm{A}$ ratio than material $5(\mathrm{e} / \mathrm{A}=4.182 \pm 0.013)$, but martensite $\alpha^{\prime \prime}$-phase is detected in material 2, while material 5 is formed only by BCC $\beta$-phase. The reason for this is that the e/A ratio increases with $\mathrm{Nb}$ (at\%) but does not consider the effect of $\mathrm{Zr}$ as a weak $\beta$-stabilizing element in Ti-Zr-Nb alloys. Nevertheless, the e/A ratio is still a useful parameter to compare different $\mathrm{Ti}-\mathrm{Zr}-\mathrm{Nb}$ alloys with a similar amount of $\mathrm{Zr}$. Despite the $\mathrm{e} / \mathrm{A}$ ratio not being accurate enough to determine constituent phases, this parameter is still a dominant factor governing the elastic constants of BCC $\beta$-type titanium alloys. 


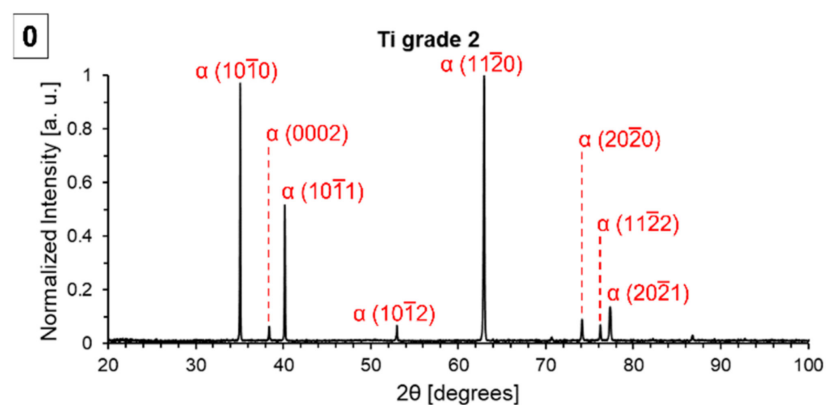

(a)

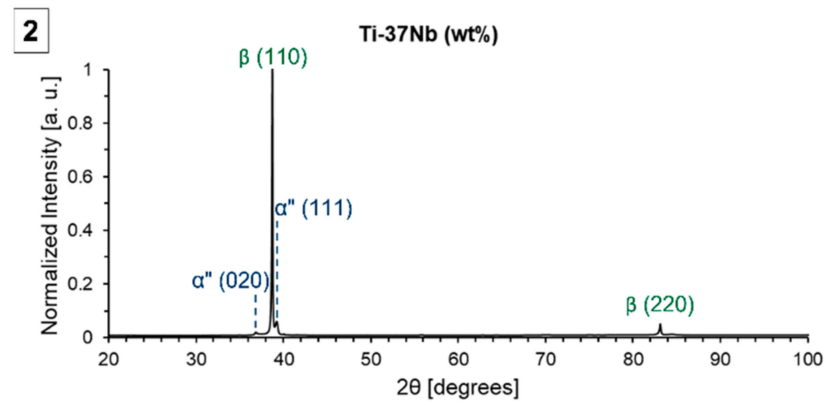

(c)

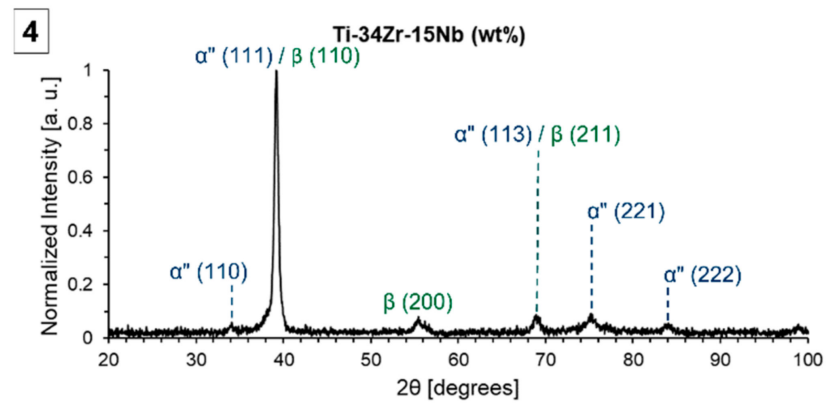

(e)

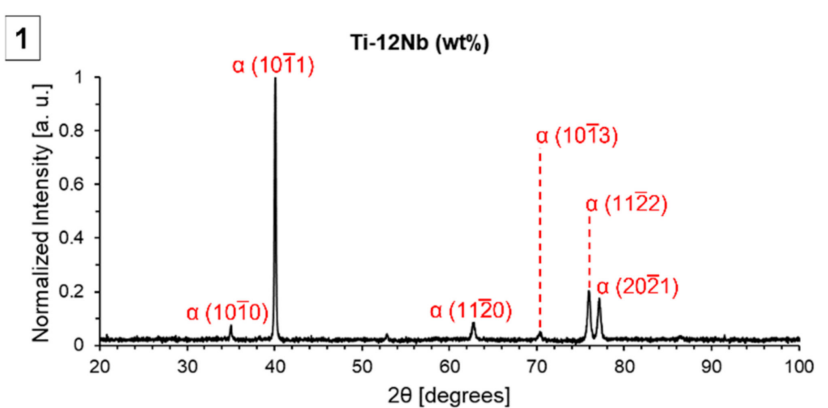

(b)

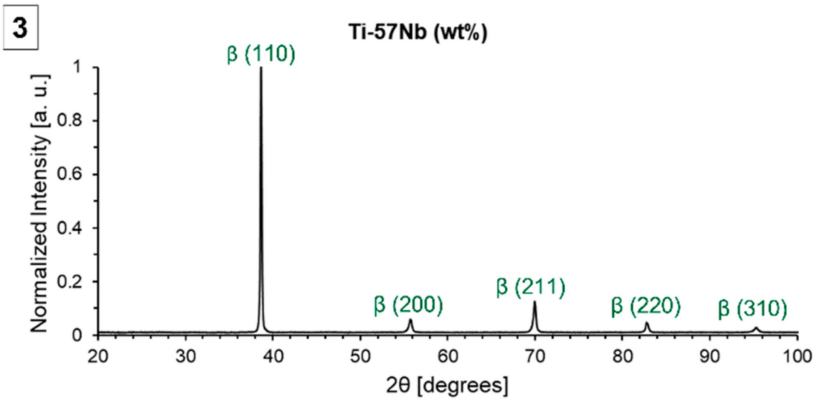

(d)

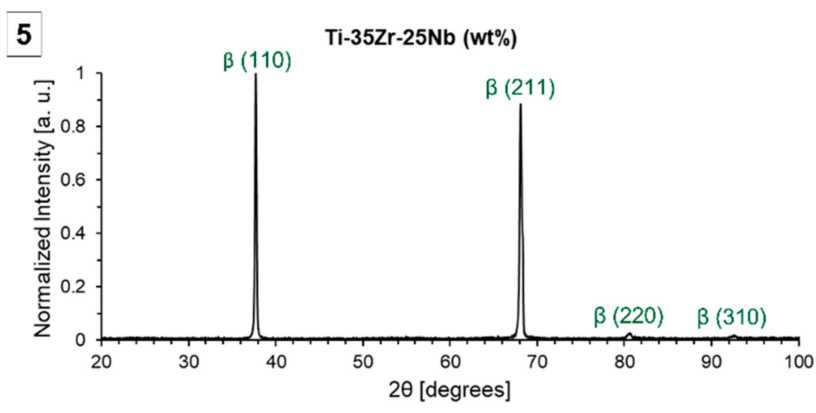

(f)

Figure 7. X-ray diffractograms of: (a) material 0, cp-Ti grade 2 substrates, (b) material 1, Ti-12Nb, (c) material 2, Ti-37Nb, (d) material 3, Ti-57Nb, (e) material 4, Ti-34Zr-15Nb, and (f) material 5, Ti-35Zr-25Nb.

The overall elastic modulus of laser-deposited $\mathrm{Ti}-\mathrm{Nb}$ and $\mathrm{Ti}-\mathrm{Zr}-\mathrm{Nb}$ alloys was studied by nanoindentation (see Figure 9). A Poisson's ratio of 0.34 was considered for all the materials to estimate their elastic modulus. Again, a sample of cp-Ti grade 2, the material employed as substrate, was included as a control. The elastic modulus of cp-Ti grade 2 measured by nanoindentation is $\mathrm{E}=106.8 \pm 2.4 \mathrm{GPa}$. The only laser-deposited material that showed a higher elastic modulus was material $1, \mathrm{Ti}-12 \mathrm{Nb}(\mathrm{E}=117.2 \pm 4.0 \mathrm{GPa})$.

Laser-deposited Ti-37Nb, Ti-57Nb, Ti-34Zr-15Nb and Ti-35Zr-25Nb alloys presented a lower elastic modulus than cp-Ti grade 2, but it is possible to find significant differences among them. If materials with a similar quantity of $\mathrm{Zr}$ are compared, the presence of the orthorhombic martensite $\alpha^{\prime \prime}$-phase increases the elastic modulus. Elastic modulus of $\alpha^{\prime \prime}+\beta$ $\mathrm{Ti}-37 \mathrm{Nb}(\mathrm{E}=90 \pm 2.6 \mathrm{GPa})$ is higher than that of $\beta \mathrm{Ti}-57 \mathrm{Nb}(\mathrm{E}=77 \pm 4.2 \mathrm{GPa})$. Similarly, $\alpha^{\prime \prime}$ $+\beta \mathrm{Ti}-34 \mathrm{Zr}-15 \mathrm{Nb}(\mathrm{E}=79 \pm 1.7 \mathrm{GPa})$ exhibits a higher elastic modulus than $\beta \mathrm{Ti}-35 \mathrm{Zr}-25 \mathrm{Nb}$ $(\mathrm{E}=70.2 \pm 1.6 \mathrm{GPa})$.

The lowest elastic modulus was observed in material 5, Ti-35Zr-25Nb (E = 70.2 $\pm 1.6 \mathrm{GPa})$. The addition of $\mathrm{Zr}$ reduced the amount of $\mathrm{Nb}$ required to fully stabilize the BCC $\beta$-phase. Furthermore, a lower amount of $\mathrm{Nb}$ decreases the e/A ratio, as well as the elastic modulus. The e/A ratio of Ti-35Zr- $25 \mathrm{Nb}(\mathrm{e} / \mathrm{A}=4.182 \pm 0.013)$ is lower than that of $\beta \mathrm{Ti}-57 \mathrm{Nb}$ 
$(\mathrm{e} / \mathrm{A}=4.408 \pm 0.011)$ or $\alpha^{\prime \prime}+\beta \mathrm{Ti}-37 \mathrm{Nb}(\mathrm{e} / \mathrm{A}=4.231 \pm 0.011)$. Therefore, the lowest elastic modulus was achieved by avoiding the formation of the orthorhombic martensite $\alpha^{\prime \prime}$-phase while keeping a small e/A ratio.

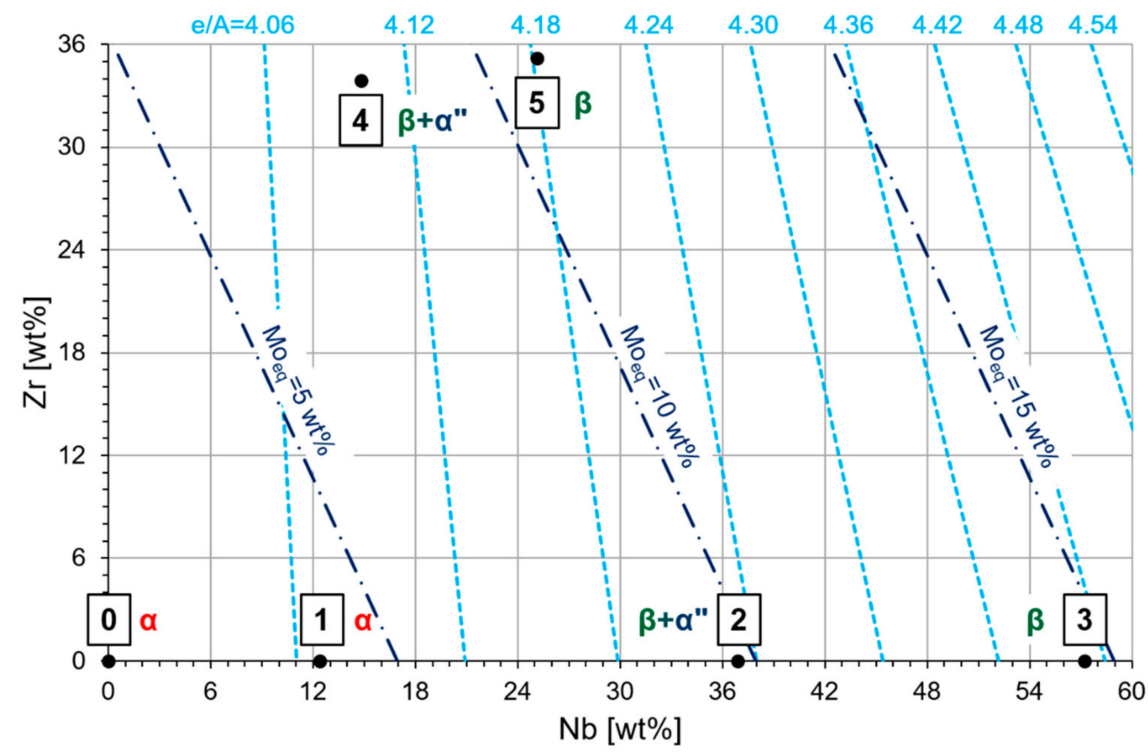

Figure 8. Diagram showing the relationship between the elemental composition, Moeq, e/A ratio, and constituent phases of laser-deposited $\mathrm{Ti}-\mathrm{Nb}$ and $\mathrm{Ti}-\mathrm{Zr}-\mathrm{Nb}$ alloys: (0) cp-Ti grade 2 substrates, (1) Ti-12Nb, (2) Ti-37Nb, (3) Ti-57Nb, (4) Ti-34Zr-15Nb, and (5) Ti-35Zr-25Nb.

$\square \mathrm{E}[\mathrm{GPa}] \otimes \mathrm{H}[\mathrm{GPa}]$

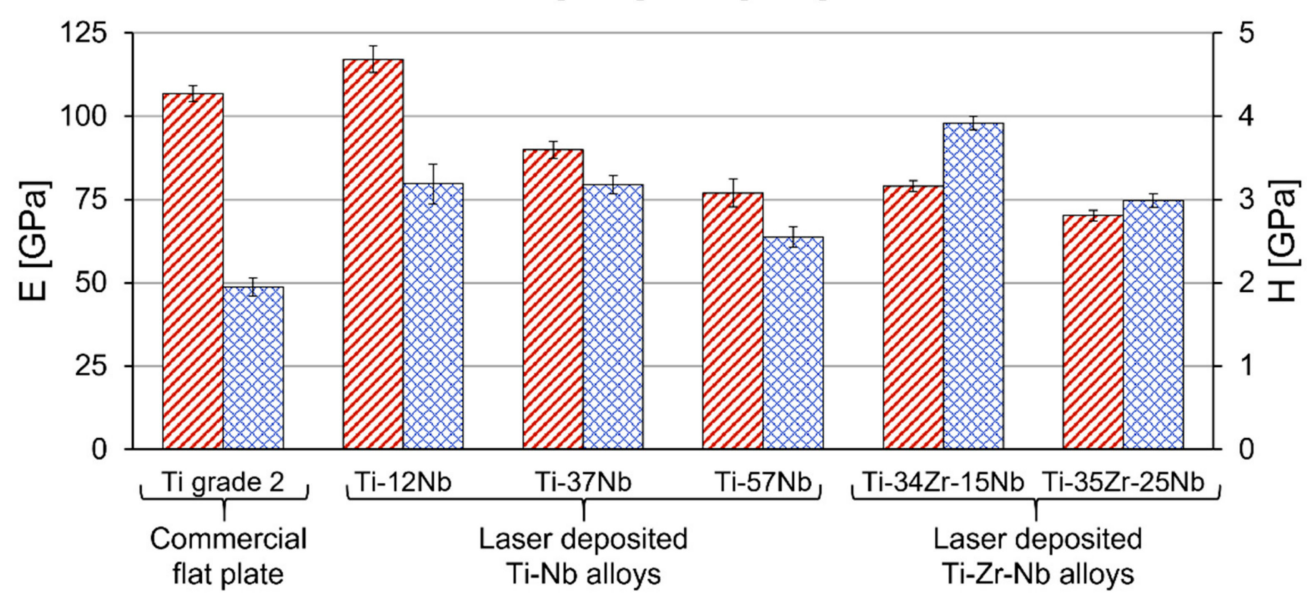

Figure 9. Measured mechanical properties from the nanoindentation test: hardness $(\mathrm{H})$ and elastic modulus (E).

The hardness of cp-Ti grade 2 and laser-deposited materials was also studied by nanoindentation (see Figure 9). All laser-deposited Ti-Nb and Ti-Zr-Nb alloys exhibited a significantly higher hardness than cp-Ti grade $2(\mathrm{H}=1.95 \pm 0.11 \mathrm{GPa})$, even when only a relatively small quantity of $\mathrm{Nb}$ was added, such as the material $1, \mathrm{Ti}-12 \mathrm{Nb}$ $(\mathrm{H}=3.19 \pm 0.24 \mathrm{GPa})$. The hardness of the rest of the materials seemed to be correlated to the presence of the orthorhombic martensite $\alpha^{\prime \prime}$-phase and the addition of $\mathrm{Zr}: \mathrm{Ti}-37 \mathrm{Nb}$ $(\mathrm{H}=3.18 \pm 0.11 \mathrm{GPa}), \mathrm{Ti}-57 \mathrm{Nb}(\mathrm{H}=2.55 \pm 0.12 \mathrm{GPa}), \mathrm{Ti}-34 \mathrm{Zr}-15 \mathrm{Nb}(\mathrm{H}=3.92 \pm 0.08 \mathrm{GPa})$, and Ti-35Zr-25Nb $(\mathrm{H}=2.99 \pm 0.08 \mathrm{GPa})$.

In addition to hardness and elastic modulus, the use of nanoindentation is also interesting to determine other parameters that can be useful to predict the wear resistance and service life of a component [51]. High hardness is indicative of good wear resistance, 
but it has been shown that elastic modulus also has an important influence on improving wear behavior [51,52]. In particular, the wear resistance of a material is related to its ability to resist elastic strain to failure, which can be described by the ratio of hardness $(\mathrm{H})$ and elastic modulus (E): $\mathrm{H} / \mathrm{E}$ ratio [27,51-54]. Similarly, $\mathrm{H}^{3} / \mathrm{E}^{2}$ ratio, a parameter that is sometimes known as yield pressure, is an indicator of the resistance to plastic deformation in loaded contact $[27,53,54]$. As the wear is the process of the gradual removal of material, which is associated with plastic deformation, $\mathrm{H}^{3} / \mathrm{E}^{2}$ is also indicative of wear resistance $[27,53,54]$. The larger $\mathrm{H} / \mathrm{E}$ and $\mathrm{H}^{3} / \mathrm{E}^{2}$ ratios are, the higher the wear resistance is.

$\mathrm{H} / \mathrm{E}$ and $\mathrm{H}^{3} / \mathrm{E}^{2}$ ratios of laser-deposited Ti-Nb and Ti-Zr-Nb alloys and the cp-Ti grade 2 control are displayed in Figure 10. Since laser-deposited Ti-Nb and Ti- $\mathrm{Zr}-\mathrm{Nb}$ materials have significantly higher hardness than cp-Ti grade 2 , and their elastic modulus is lower or similar (e.g., Ti-12Nb), they exhibit greater $\mathrm{H} / \mathrm{E}$ and $\mathrm{H}^{3} / \mathrm{E}^{2}$ ratios. The variable trend of $\mathrm{H}^{3} / \mathrm{E}^{2}$ ratio is the same as that of the $\mathrm{H} / \mathrm{E}$ ratio. Materials can be ordered, from highest to lowest $\mathrm{H} / \mathrm{E}$ and $\mathrm{H}^{3} / \mathrm{E}^{2}$ ratios, as follows: Ti-34Zr- $15 \mathrm{Nb}>\mathrm{Ti}-35 \mathrm{Zr}-25 \mathrm{Nb}>\mathrm{Ti}-$ $37 \mathrm{Nb}>\mathrm{Ti}-57 \mathrm{Nb}>\mathrm{Ti}-12 \mathrm{Nb}>$ Ti grade 2 . Therefore, a better wear resistance and a longer service life as biomedical materials could be expected from laser-deposited Ti-Nb and Ti-Zr-Nb alloys.

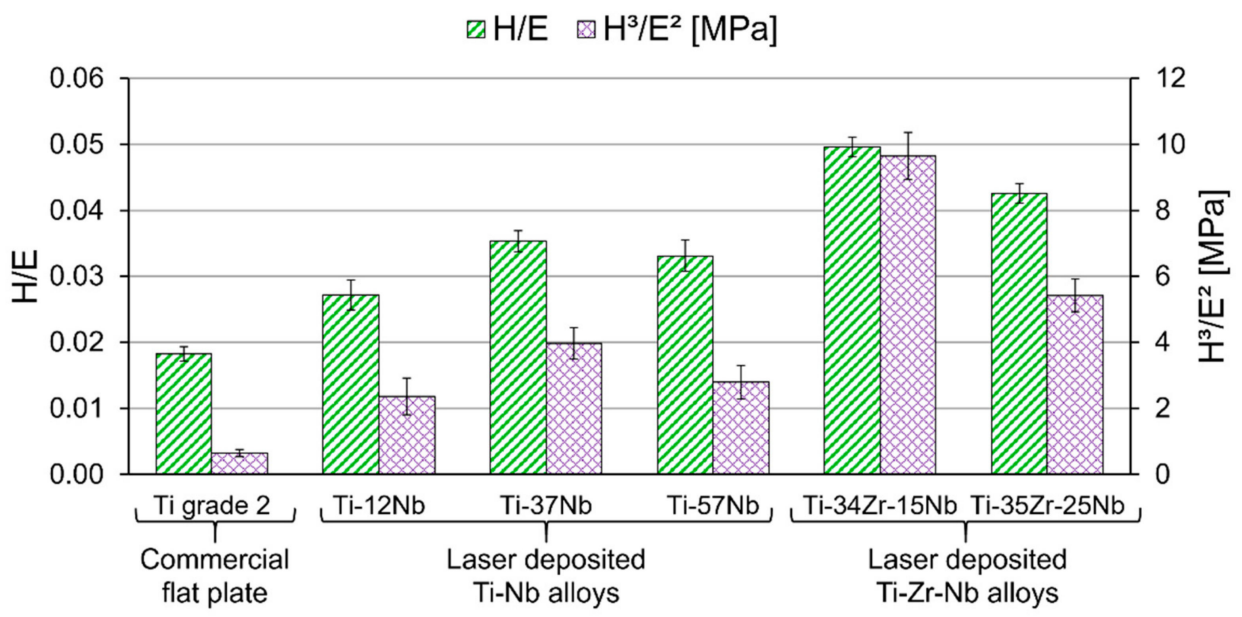

Figure 10. Parameters associated with wear resistance: $\mathrm{H} / \mathrm{E}$ ratio and $\mathrm{H}^{3} / \mathrm{E}^{2}$ ratio.

Figure 11 shows the potentiodynamic polarization curves of the cp-Ti grade 2 control and the laser-deposited materials in phosphate buffered saline (PBS) solution at $37.0 \pm 0.5^{\circ} \mathrm{C}$. Firstly, with the increase of potential in the cathodic branch, the current density drops. After a certain potential $\left(\mathrm{E}_{\mathrm{corr}}\right)$ is reached, the current density rises with the increase of potential (anodic branch). By considering the cathodic and anodic branches, the corrosion current densities $\left(\mathrm{i}_{\mathrm{corr}}\right)$ and corrosion potential $\left(\mathrm{E}_{\mathrm{corr}}\right)$ were calculated by Tafel extrapolation analysis, as listed in Table 4. With further increasing potential, the active-to-passive transition corresponds to the formation of a passive protective oxide film on the surface of the material. It was found that all anodic branches of the potentiodynamic polarization curves showed no significant differences in shape. As can be seen, in the passive region, the passive current density $\left(i_{p}\right)$ remains almost unchanged over a wide potential range $\left(E_{b}-E_{p}[V]\right)$, demonstrating that a stable passive film is formed on all the materials in those ranges of potential. After passivation, and with increasing potential, a slight rise in the current density is observed for all the materials. In addition to the corrosion potential $\left(\mathrm{E}_{\mathrm{corr}}\right)$ and the corrosion current density $\left(\mathrm{i}_{\mathrm{corr}}\right)$, passivation potential $\left(E_{p}\right)$, passive current density $\left(i_{p}\right)$, and breakdown potential $\left(E_{b}\right)$, values are presented in Table 4. Finally, the scanning potential direction is reversed and the current density decreases, demonstrating a negative hysteresis for the cp-Ti grade 2 control and all the laser-deposited materials. Stability of passive behavior at higher potentials than $\mathrm{E}_{\mathrm{corr}}$ and the negative hysteresis in the cyclic polarization curves confirm the excellent corrosion resistance of the laser-deposited $\mathrm{Ti}-\mathrm{Nb}$ and $\mathrm{Ti}-\mathrm{Zr}-\mathrm{Nb}$ alloys. 
0

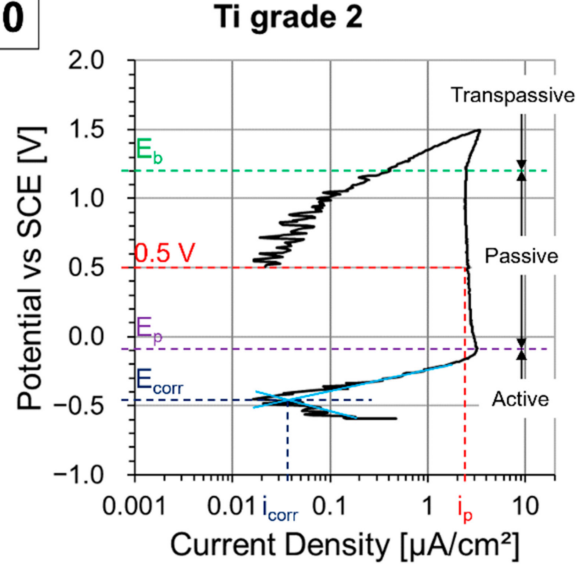

(a)

2

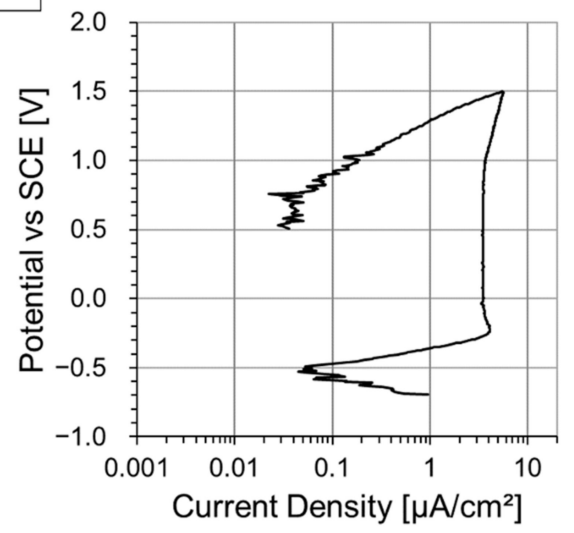

(c)

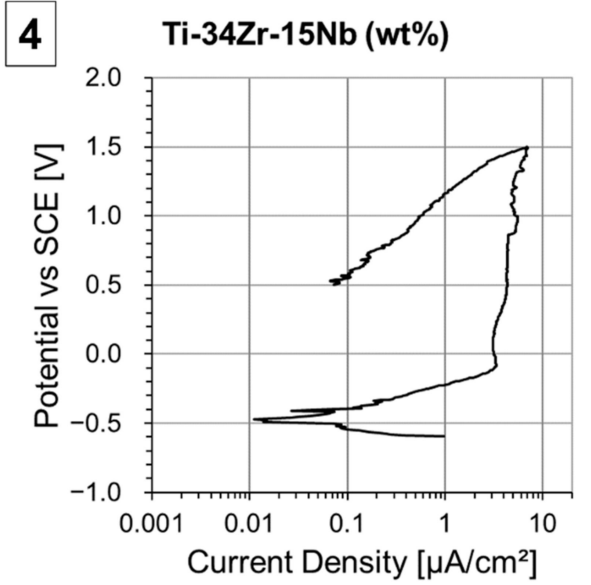

(e)
1

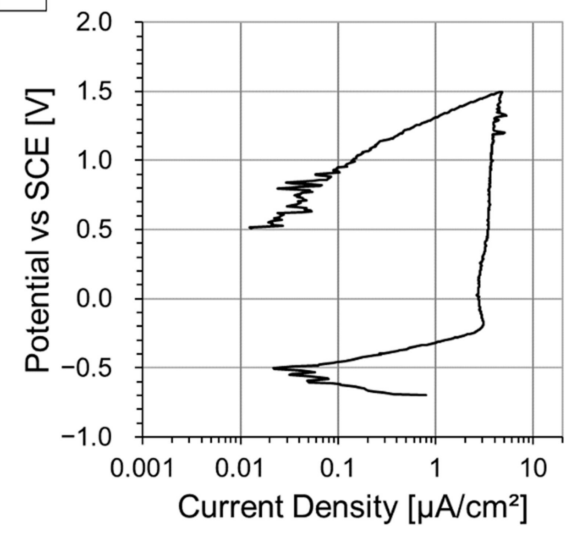

(b)

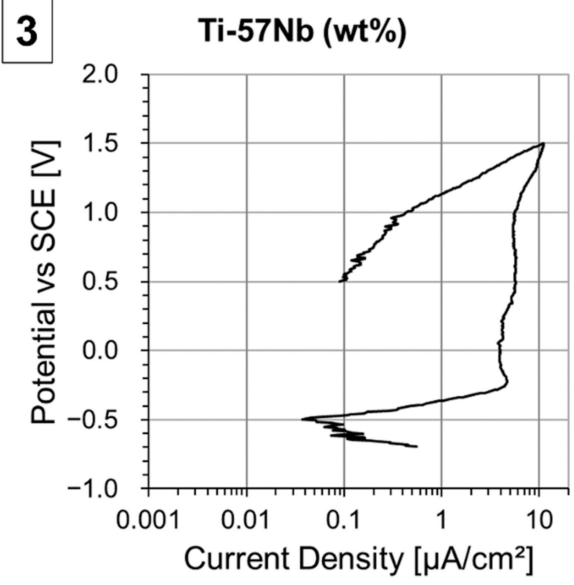

(d)

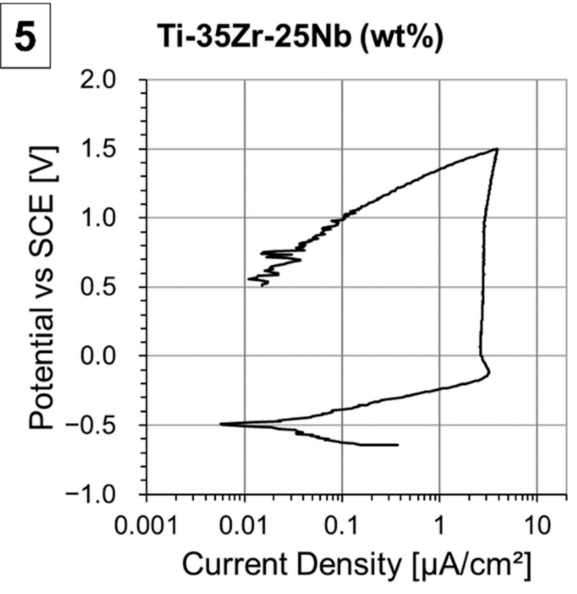

(f)

Figure 11. Potentiodynamic polarization curves of: (a) cp-Ti grade 2 substrates, (b) Ti-12Nb, (c) Ti$37 \mathrm{Nb}$, (d) Ti-57Nb, (e) Ti-34Zr-15Nb, and (f) Ti-35Zr-25Nb. Corrosion potential ( $\mathrm{E}_{\mathrm{corr}}$ ), corrosion current density $\left(\mathrm{i}_{\mathrm{corr}}\right)$, passivation potential $\left(\mathrm{E}_{\mathrm{p}}\right)$, passive current density $\left(\mathrm{i}_{\mathrm{p}}\right)$, and breakdown potential $\left(E_{b}\right)$. 
Table 4. Corrosion potential $\left(\mathrm{E}_{\mathrm{corr}}\right)$, corrosion current density $\left(\mathrm{i}_{\mathrm{corr}}\right)$, passivation potential $\left(\mathrm{E}_{\mathrm{p}}\right)$, passive current density ( $\left.\mathrm{i}_{\mathrm{p}}\right)$, and breakdown potential $\left(\mathrm{E}_{\mathrm{b}}\right)$ values obtained from potentiodynamic polarization tests in phosphate buffered saline (PBS) solution at $37.0 \pm 0.5^{\circ} \mathrm{C}$.

\begin{tabular}{|c|c|c|c|c|c|c|c|c|}
\hline Material & Alloy & $\mathrm{E}_{\text {corr }}[\mathrm{V}]$ & $i_{\text {corr }}\left[\mu \mathrm{A} / \mathrm{cm}^{2}\right]$ & $E_{p}[V]$ & $i_{p}\left[\mu \mathrm{A} / \mathrm{cm}^{2}\right]$ & $\mathrm{Eb}[\mathrm{V}]$ & Ep-Ecorr [V] & Eb-Ep [V] \\
\hline 0 & Ti grade 2 & $-0.46 \pm 0.01$ & $0.045 \pm 0.005$ & $-0.09 \pm 0.01$ & $2.60 \pm 0.05$ & $1.22 \pm 0.01$ & $0.35 \pm 0.02$ & $1.31 \pm 0.02$ \\
\hline 1 & $\mathrm{Ti}-12 \mathrm{Nb}$ & $-0.53 \pm 0.01$ & $0.050 \pm 0.005$ & $-0.18 \pm 0.01$ & $3.43 \pm 0.07$ & $1.19 \pm 0.01$ & $0.35 \pm 0.02$ & $1.37 \pm 0.02$ \\
\hline 2 & $\mathrm{Ti}-37 \mathrm{Nb}$ & $-0.52 \pm 0.01$ & $0.080 \pm 0.005$ & $-0.22 \pm 0.01$ & $3.48 \pm 0.07$ & $1.00 \pm 0.01$ & $0.30 \pm 0.02$ & $1.22 \pm 0.02$ \\
\hline 3 & $\mathrm{Ti}-57 \mathrm{Nb}$ & $-0.53 \pm 0.01$ & $0.060 \pm 0.005$ & $-0.23 \pm 0.01$ & $5.70 \pm 0.10$ & $1.00 \pm 0.01$ & $0.30 \pm 0.02$ & $1.23 \pm 0.02$ \\
\hline 4 & Ti-34Zr-15Nb & $-0.48 \pm 0.01$ & $0.050 \pm 0.005$ & $-0.08 \pm 0.01$ & $4.34 \pm 0.08$ & $1.19 \pm 0.01$ & $0.40 \pm 0.02$ & $1.27 \pm 0.02$ \\
\hline 5 & $\mathrm{Ti}-35 \mathrm{Zr}-25 \mathrm{Nb}$ & $-0.50 \pm 0.01$ & $0.020 \pm 0.005$ & $-0.12 \pm 0.01$ & $2.79 \pm 0.05$ & $1.00 \pm 0.01$ & $0.38 \pm 0.02$ & $1.12 \pm 0.02$ \\
\hline
\end{tabular}

Human osteosarcoma SaOS-2 cells were used to assess the in vitro cytocompatibility of the laser-deposited Ti-Nb and Ti-Zr-Nb alloys compared to the cp-Ti grade 2 control. Previously, the surfaces of the materials were treated with $\mathrm{SiC}$ paper to obtain a surface with a similar roughness in all the samples $(\mathrm{Ra}=2.0 \pm 0.4 \mu \mathrm{m})$. This roughness value is of the same order of magnitude as that of real implants after shot blasting [5]. The morphology of the SaOS-2 cells attached to the surfaces of the alloys is shown in Figure 12. Regarding cell shape, attachment, and spreading, SaOS-2 cells grown on laser-deposited materials and $\mathrm{cp}$-Ti grade 2 showed distinct, well-developed actin cytoskeletons and vinculin plaques (Figure 12b). In general, the cells exhibited a flattened cellular morphology with a high level of attachment, which indicates that the cells spread well on the surfaces of $\mathrm{cp}$-Ti grade 2 and the laser-deposited alloys (Figure 12). This is an indication that the initial cell adhesion and the growth of the cells were healthy and strong. Thus, it can be concluded that the laser-deposited $\mathrm{Ti}-\mathrm{Nb}$ and $\mathrm{Ti}-\mathrm{Zr}-\mathrm{Nb}$ alloys are favorable for cell growth and proliferation.

Cell count after $24 \mathrm{~h}$ of culture showed a lower number of SaOS-2 cells on cp-Ti grade 2 compared to the laser-deposited alloys. The adhesion of osteoblasts-like cells was 6-, 11-, 7-, 10-, and 7-fold higher on the Ti-12Nb, Ti-37Nb, Ti-57Nb, Ti-34Zr- $15 \mathrm{Nb}$, and Ti-35Zr-25Nb alloys, respectively (Figure 13). These significant differences between the substrates of cp-Ti grade 2 and the laser-deposited alloys may be related to the presence of more cytocompatible alloying elements, such as $\mathrm{Nb}$ and $\mathrm{Zr}$ [4,55]. There are no significant differences in cell area and length of the FA between the laser-deposited materials and cp-Ti grade 2 (Figure 14). Since all the analyses showed that the laser-deposited Ti-Nb and Ti-Zr-Nb alloys had a better or similar behavior to that of the cp-Ti grade 2 control, it can be concluded that they possess excellent cytocompatibility.

Laser Directed Energy Deposition is a feasible technique to produce in situ biomedical $\mathrm{Ti}-\mathrm{Nb}$ and Ti-Zr- $\mathrm{Nb}$ alloys ranging from $0 \mathrm{wt} \% \mathrm{Zr}$ to $35 \mathrm{wt} \% \mathrm{Zr}$ from elemental powders. This additive manufacturing technique requires smaller amounts of precursor material than SLM or other more conventional manufacturing process. Moreover, it can produce specimens without relevant defects, such as pores or cracks. In-situ Laser Directed Energy Deposition allows for the obtaining of titanium alloys with low elastic modulus, excellent corrosion resistance, and outstanding in vitro cytocompatibility. Particularly, the laserdeposited Ti-35Zr-25Nb alloy has an elastic modulus 34\% lower than that of $\mathrm{cp}$-Ti grade 2 $(\mathrm{E}=106.8 \pm 2.4 \mathrm{GPa})$, and is $36-39 \%$ lower than that of the Ti-6Al-4V alloy $[1,56,57]$, the most used in applications in traumatology and orthopedics. Ti-35Zr-25Nb alloy has very good properties in order to avoid stress shielding problems. 
a)

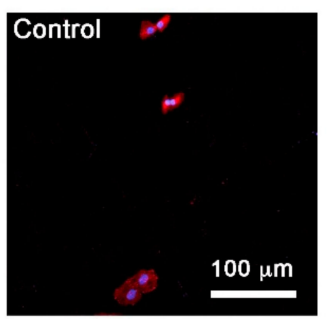

\section{b)}
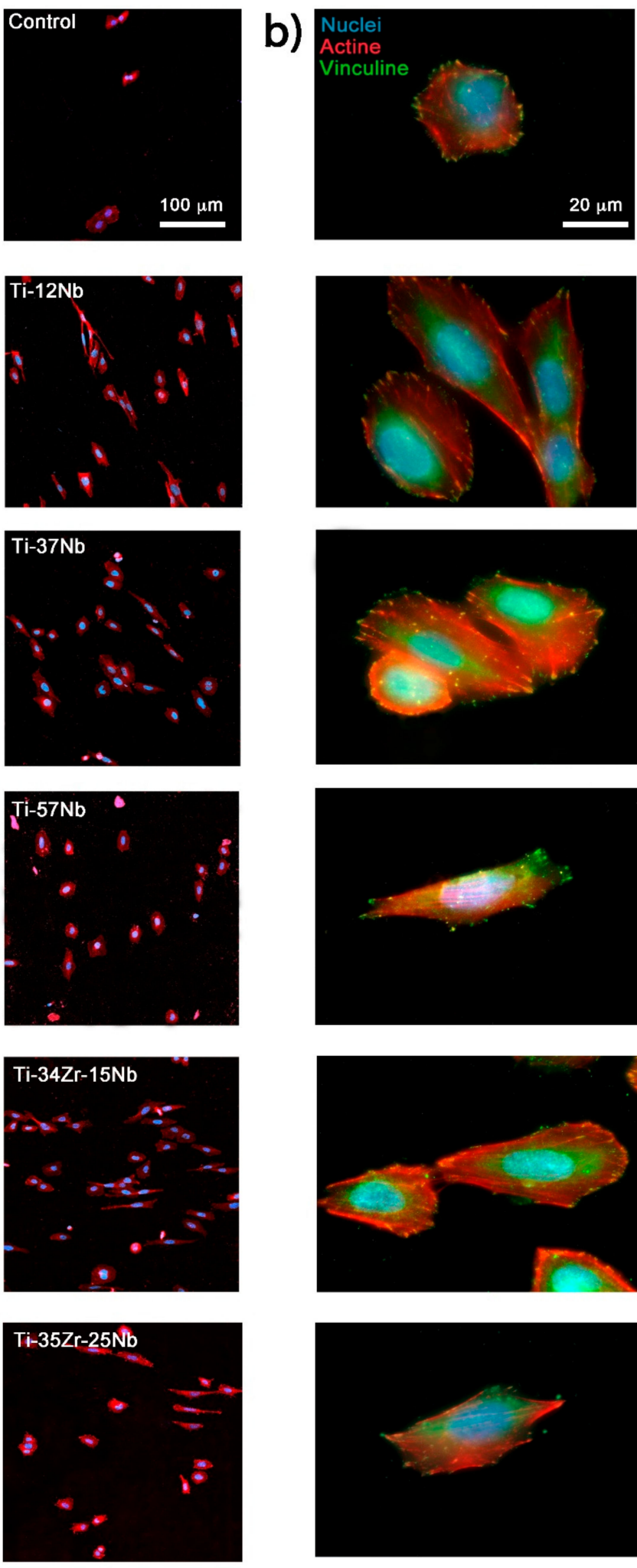
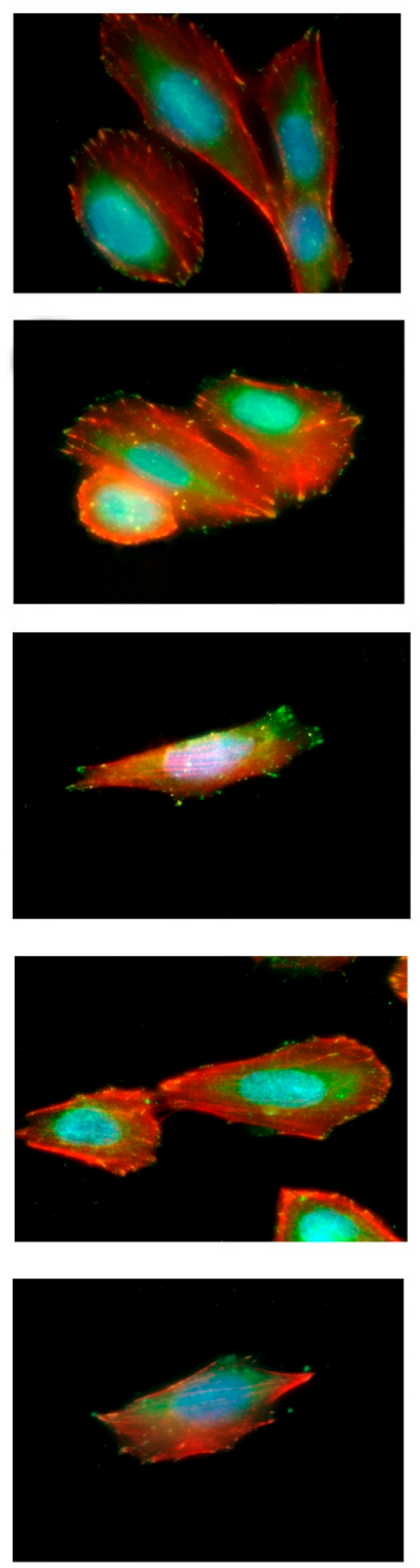

c)
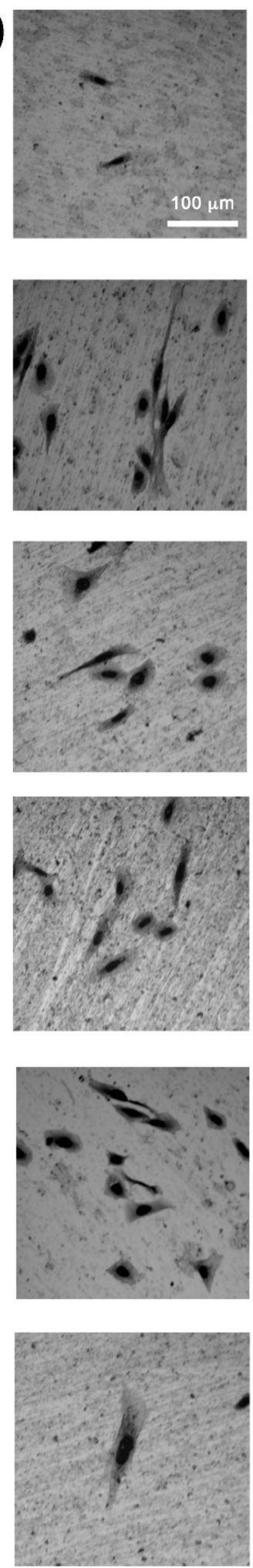

Figure 12. (a) Optical micrographs showing adherence of the SaOS-2 cells to the surfaces of the materials. (b) Optical micrographs detailing the morphology of the SaOS-2 cells. (c) SEM micrographs showing the SaOS-2 cells on the surfaces of the different materials. 


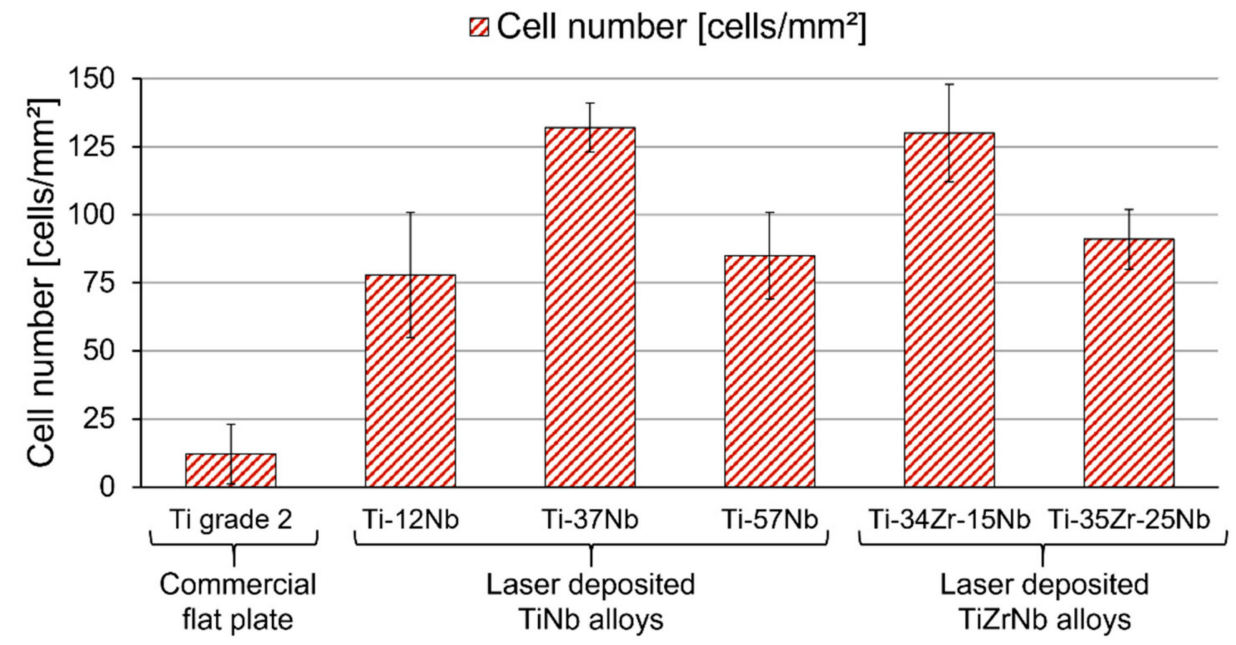

Figure 13. Measured cell number from the cytocompatibility assessment (Error bars represent standard deviation).

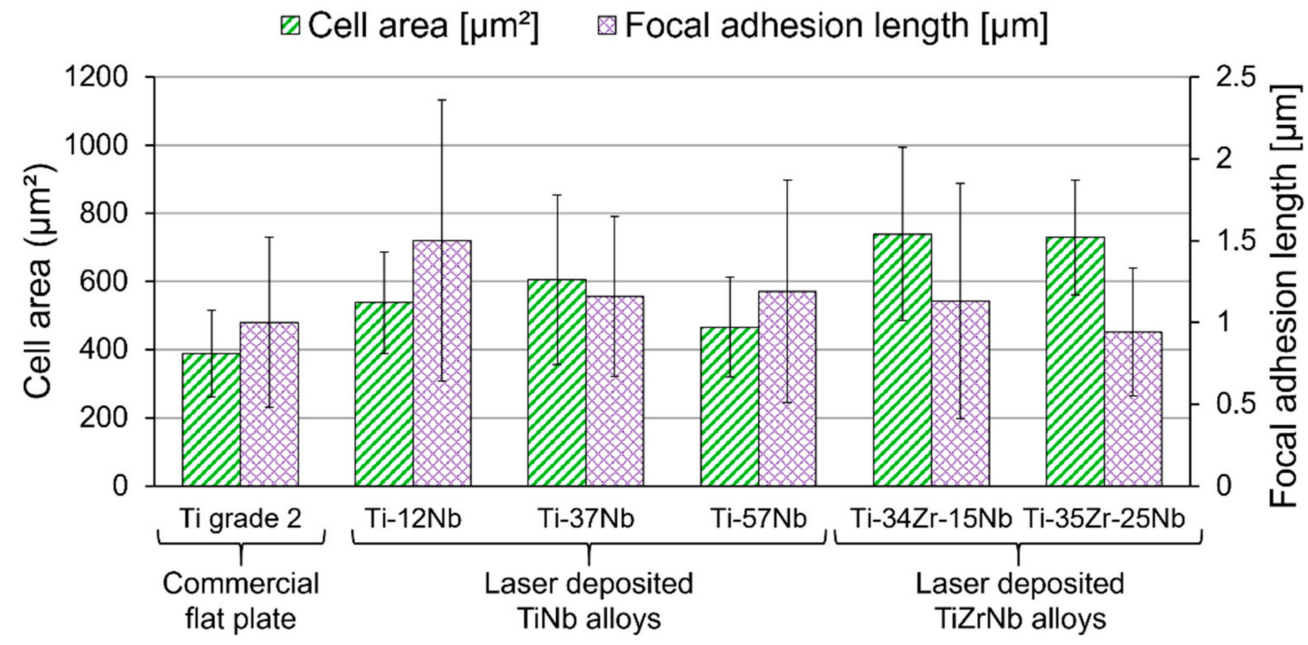

Figure 14. Measured cell area and focal adhesion length from the cytocompatibility assessment (Error bars represent standard deviation).

\section{Conclusions}

The feasibility of the Laser Directed Energy Deposition technique to produce in situ biomedical Ti-Nb and Ti-Zr-Nb alloys ranging from $0 \mathrm{wt} \% \mathrm{Zr}$ to $35 \mathrm{wt} \% \mathrm{Zr}$ from elemental powders has been demonstrated. Laser-deposited specimens showed no relevant defects, such as pores or cracks. The microstructure of the different materials consisted of large, elongated columnar prior $\beta$ grains that grow in parallel to the building direction, except in the upper part of the piece, where equiaxed grains were formed. Laser-deposited Ti- $37 \mathrm{Nb}$, Ti- $57 \mathrm{Nb}$, Ti-34Zr- $15 \mathrm{Nb}$, and Ti-35Zr-25Nb alloys exhibit a lower elastic modulus than cp-Ti grade 2. The lowest elastic modulus was observed in laser-deposited Ti-35Zr-25Nb: $\mathrm{E}=70.2 \pm 1.6 \mathrm{GPa}$, which was $34 \%$ lower than that of $\mathrm{cp}$-Ti grade $2(\mathrm{E}=106.8 \pm 2.4 \mathrm{GPa})$. Since laser-deposited $\mathrm{Ti}-\mathrm{Nb}$ and $\mathrm{Ti}-\mathrm{Zr}-\mathrm{Nb}$ materials have significantly higher hardness than cp-Ti grade 2 and their elastic modulus is lower or similar (e.g., Ti-12Nb), a better wear resistance and a longer service life as biomedical materials could be expected from them. Moreover, laser-deposited $\mathrm{Ti}-\mathrm{Nb}$ and $\mathrm{Ti}-\mathrm{Zr}-\mathrm{Nb}$ alloys have an excellent corrosion resistance due to the formation of a stable passive protective oxide film on the surface of the material; they also possess outstanding cytocompatibility. Particularly, laser-deposited Ti-35Zr- $25 \mathrm{Nb}$ is a promising material for orthopedic and dental applications, as it shows 
the lowest elastic modulus in combination with an increased hardness, good corrosion resistance, and excellent biocompatibility in vitro.

Author Contributions: Conceptualization, F.A.-G., J.M.M., F.J.G. and J.P.; methodology, F.A.-G., A.R.-C. and M.P.; validation, Ó.B., M.F.-A. and F.L.; formal analysis, Ó.B., M.F.-A. and F.L.; investigation, F.A.-G., A.R.-C. and M.P.; data curation, F.A.-G., A.R.-C. and M.P.; writing-original draft preparation, F.A.-G. and A.R.-C.; writing - review and editing, M.P., J.M.M. and J.P.; funding acquisition, J.M.M., F.J.G. and J.P. All authors have read and agreed to the published version of the manuscript.

Funding: This research was partially funded by SOADCO S.L. (Escaldes Engordany, Andorra), by the Government of Spain (RTI2018-098075-B-C21), by Xunta de Galicia (ED431C 2019/2) and by the EU through the European Regional Development Funds (MINECO-FEDER, EU). Authors also acknowledge Generalitat de Catalunya for its funding through the 2017 SGR-1165 project.

Institutional Review Board Statement: Not applicable.

Informed Consent Statement: Not applicable.

Data Availability Statement: All data needed to evaluate the conclusions in the paper are present in the paper. Additional data related to this paper may be requested from the authors.

Acknowledgments: The authors wish to thank the technical staff from CACTI (Universidade de Vigo), Barcelona Research Center in Multiscale Science and Engineering (Universitat Politècnica de Catalunya) and CCiTUB (Universitat de Barcelona) for their technical assistance with the characterization techniques. Technical assistance of A. Abalde (Universidade de Vigo) is also acknowledged.

Conflicts of Interest: The authors declare no conflict of interest. The funders had no role in the design of the study; in the collection, analyses, or interpretation of data; in the writing of the manuscript, or in the decision to publish the results.

\section{References}

1. Li, Y.; Yang, C.; Zhao, H.; Qu, S.; Li, X.; Li, Y. New developments of ti-based alloys for biomedical applications. Materials 2014, 7, 1709-1800. [CrossRef]

2. Kaur, M.; Singh, K. Review on titanium and titanium based alloys as biomaterials for orthopaedic applications. Mater. Sci. Eng. C 2019, 102, 844-862. [CrossRef] [PubMed]

3. Zhang, L.C.; Chen, L.Y. A review on biomedical titanium alloys: Recent progress and prospect. Adv. Eng. Mater. 2019, $21,1801215$. [CrossRef]

4. Biesiekierski, A.; Wang, J.; Abdel-Hady Gepreel, M.; Wen, C. A new look at biomedical Ti-based shape memory alloys. Acta Biomater. 2012, 8, 1661-1669. [CrossRef] [PubMed]

5. Brizuela, A.; Herrero-Climent, M.; Rios-Carrasco, E.; Rios-Santos, J.V.; Pérez, R.A.; Manero, J.M.; Mur, J.G. Influence of the elastic modulus on the osseointegration of dental implants. Materials 2019, 12, 980. [CrossRef]

6. Kolli, R.P.; Devaraj, A. A review of metastable beta titanium alloys. Metals 2018, 8, 506. [CrossRef]

7. Elmay, W.; Patoor, E.; Gloriant, T.; Prima, F.; Laheurte, P. Improvement of superelastic performance of Ti-Nb binary alloys for biomedical applications. J. Mater. Eng. Perform. 2014, 23, 2471-2476. [CrossRef]

8. Kim, S.E.; Jeong, H.W.; Hyun, Y.T.; Lee, Y.T.; Jung, C.H.; Kim, S.K.; Song, J.S.; Lee, J.H. Elastic modulus and in vitro biocompatibility of Ti-xNb and Ti-xTa alloys. Met. Mater. Int. 2007, 13, 145-149. [CrossRef]

9. Zhou, Y.L.; Niinomi, M.; Akahori, T. Effects of Ta content on Young's modulus and tensile properties of binary Ti-Ta alloys for biomedical applications. Mater. Sci. Eng. A 2004, 371, 283-290. [CrossRef]

10. Kim, J.I.; Kim, H.Y.; Inamura, T.; Hosoda, H.; Miyazaki, S. Shape memory characteristics of Ti-22Nb-(2-8)Zr(at.\%) biomedical alloys. Mater. Sci. Eng. A 2005, 403, 334-339. [CrossRef]

11. Martins, D.Q.; Osório, W.R.; Souza, M.E.P.; Caram, R.; Garcia, A. Effects of Zr content on microstructure and corrosion resistance of Ti-30Nb-Zr casting alloys for biomedical applications. Electrochim. Acta 2008, 53, 2809-2817. [CrossRef]

12. Ning, C.; Ding, D.; Dai, K.; Zhai, W.; Chen, L. The effect of Zr content on the microstructure, mechanical properties and cell attachment of Ti-35Nb-xZr alloys. Biomed. Mater. 2010, 5, 045006. [CrossRef] [PubMed]

13. Meng, Q.; Guo, S.; Liu, Q.; Hu, L.; Zhao, X. A $\beta$-type TiNbZr alloy with low modulus and high strength for biomedical applications. Prog. Nat. Sci. Mater. Int. 2014, 24, 157-162. [CrossRef]

14. Ozan, S.; Lin, J.; Li, Y.; Ipek, R.; Wen, C. Development of Ti-Nb-Zr alloys with high elastic admissible strain for temporary orthopedic devices. Acta Biomater. 2015, 20, 176-187. [CrossRef]

15. Kim, K.M.; Kim, H.Y.; Miyazaki, S. Effect of Zr content on phase stability, deformation behavior, and young's modulus in Ti-Nb-Zr alloys. Materials 2020, 13, 476. [CrossRef] 
16. Kuroda, P.A.B.; de Quadros, F.F.; Oliveira de Araújo, R.; Afonso, C.R.M.; Grandini, C.R. Effect of thermomechanical treatments on the phases, microstructure, microhardness and young's modulus of ti-25ta-zr alloys. Materials 2019, 12, 3210. [CrossRef]

17. Kuroda, P.A.B.; de Quadros, F.F.; Afonso, C.R.M.; Grandini, C.R. The effect of solution heat treatment temperature on phase transformations, microstructure and properties of Ti-25Ta-xZr alloys used as a biomaterial. J. Mater. Eng. Perform. 2020, 29, 2410-2417. [CrossRef]

18. González, M.; Peña, J.; Gil, F.J.; Manero, J.M. Low modulus Ti-Nb-Hf alloy for biomedical applications. Mater. Sci. Eng. C 2014, 42, 691-695. [CrossRef]

19. Herranz-Diez, C.; Gil, F.J.; Guillem-Marti, J.; Manero, J.M. Mechanical and physicochemical characterization along with biological interactions of a new Ti25Nb21Hf alloy for bone tissue engineering. J. Biomater. Appl. 2015, 30, 171-181. [CrossRef]

20. Li, S.J.; Yang, R.; Li, S.; Hao, Y.L.; Cui, Y.Y.; Niinomi, M.; Guo, Z.X. Wear characteristics of Ti-Nb-Ta-Zr and Ti-6Al-4V alloys for biomedical applications. Wear 2004, 257, 869-876. [CrossRef]

21. Laheurte, P.; Prima, F.; Eberhardt, A.; Gloriant, T.; Wary, M.; Patoor, E. Mechanical properties of low modulus $\beta$ titanium alloys designed from the electronic approach. J. Mech. Behav. Biomed. Mater. 2010, 3, 565-573. [CrossRef] [PubMed]

22. Nakai, M.; Niinomi, M.; Oneda, T. Improvement in fatigue strength of biomedical $\beta$-type Ti-Nb-Ta-Zr alloy while maintaining low young's modulus through optimizing w-phase precipitation. Metall. Mater. Trans. A Phys. Metall. Mater. Sci. 2012, 43, 294-302. [CrossRef]

23. Ozan, S.; Lin, J.; Li, Y.; Wen, C. New Ti-Ta-Zr-Nb alloys with ultrahigh strength for potential orthopedic implant applications. J. Mech. Behav. Biomed. Mater. 2017, 75, 119-127. [CrossRef]

24. Chen, J.; Ma, F.; Liu, P.; Wang, C.; Liu, X.; Li, W.; Han, Q. Effects of Nb on Superelasticity and Low Modulus Properties of Metastable $\beta$-Type Ti-Nb-Ta-Zr Biomedical Alloys. J. Mater. Eng. Perform. 2019, 28, 1410-1418. [CrossRef]

25. Miura, K.; Yamada, N.; Hanada, S.; Jung, T.K.; Itoi, E. The bone tissue compatibility of a new Ti-Nb-Sn alloy with a low Young's modulus. Acta Biomater. 2011, 7, 2320-2326. [CrossRef]

26. Guo, S.; Meng, Q.; Zhao, X.; Wei, Q.; Xu, H. Design and fabrication of a metastable $\beta$-type titanium alloy with ultralow elastic modulus and high strength. Sci. Rep. 2015, 5, 1-8. [CrossRef]

27. Li, P.; Ma, X.; Wang, D.; Zhang, H. Microstructural and mechanical properties of $\beta$-type ti-nb-sn biomedical alloys with low elastic modulus. Metals 2019, 9, 712. [CrossRef]

28. Hao, Y.L.; Li, S.J.; Sun, S.Y.; Zheng, C.Y.; Yang, R. Elastic deformation behaviour of Ti-24Nb-4Zr-7.9Sn for biomedical applications. Acta Biomater. 2007, 3, 277-286. [CrossRef]

29. Li, S.; Nam, T. hyun Superelasticity and tensile strength of Ti-Zr-Nb-Sn alloys with high Zr content for biomedical applications. Intermetallics 2019, 112, 106545. [CrossRef]

30. Saboori, A.; Gallo, D.; Biamino, S.; Fino, P.; Lombardi, M. An overview of additive manufacturing of titanium components by directed energy deposition: Microstructure and mechanical properties. Appl. Sci. 2017, 7, 883. [CrossRef]

31. Barro, Ó.; Arias-González, F.; Lusquiños, F.; Comesaña, R.; Del Val, J.; Riveiro, A.; Badaoui, A.; Gómez-Baño, F.; Pou, J. Effect of four manufacturing techniques (Casting, laser directed energy deposition, milling and selective laser melting) on microstructural, mechanical and electrochemical properties of co-cr dental alloys, before and after pfm firing process. Metals 2020, $10,1291$. [CrossRef]

32. Comesaña, R.; Lusquiños, F.; Del Val, J.; Quintero, F.; Riveiro, A.; Boutinguiza, M.; Jones, J.R.; Hill, R.G.; Pou, J. Toward smart implant synthesis: Bonding bioceramics of different resorbability to match bone growth rates. Sci. Rep. 2015, 5, 10677. [CrossRef]

33. Comesaña, R.; Lusquiños, F.; Del Val, J.; López-Álvarez, M.; Quintero, F.; Riveiro, A.; Boutinguiza, M.; De Carlos, A.; Jones, J.R.; Hill, R.G.; et al. Three-dimensional bioactive glass implants fabricated by rapid prototyping based on $\mathrm{CO}_{2}$ laser cladding. Acta Biomater. 2011, 7, 3476-3487. [CrossRef] [PubMed]

34. Arias-González, F.; del Val, J.; Comesaña, R.; Penide, J.; Lusquiños, F.; Quintero, F.; Riveiro, A.; Boutinguiza, M.; Gil, F.J.; Pou, J. Microstructure and crystallographic texture of pure titanium parts generated by laser additive manufacturing. Met. Mater. Int. 2018, 24, 231-239. [CrossRef]

35. Xue, W.; Krishna, B.V.; Bandyopadhyay, A.; Bose, S. Processing and biocompatibility evaluation of laser processed porous titanium. Acta Biomater. 2007, 3, 1007-1018. [CrossRef] [PubMed]

36. Krishna, B.V.; Bose, S.; Bandyopadhyay, A. Low stiffness porous Ti structures for load-bearing implants. Acta Biomater. 2007, 3, 997-1006. [CrossRef] [PubMed]

37. Dinda, G.P.; Song, L.; Mazumder, J. Fabrication of Ti-6Al-4V scaffolds by direct metal deposition. Metall. Mater. Trans. A Phys. Metall. Mater. Sci. 2008, 39, 2914-2922. [CrossRef]

38. Fischer, M.; Laheurte, P.; Acquier, P.; Joguet, D.; Peltier, L.; Petithory, T.; Anselme, K.; Mille, P. Synthesis and characterization of Ti-27.5Nb alloy made by CLAD ${ }^{\circledR}$ additive manufacturing process for biomedical applications. Mater. Sci. Eng. C 2017, 75, 341-348. [CrossRef]

39. Banerjee, R.; Nag, S.; Samuel, S.; Fraser, H.L. Laser-deposited Ti-Nb-Zr-Ta orthopedic alloys. J. Biomed. Mater. Res. Part A 2006, 78, 298-305. [CrossRef]

40. Samuel, S.; Nag, S.; Nasrazadani, S.; Ukirde, V.; El Bouanani, M.; Mohandas, A.; Nguyen, K.; Banerjee, R. Corrosion resistance and in vitro response of laser-deposited Ti-Nb-Zr-Ta alloys for orthopedic implant applications. J. Biomed. Mater. Res. Part A 2010, 94, 1251-1256. [CrossRef] 
41. Nagn, S.; Banerjee, R. Laser deposition and deformation behavior of Ti-Nb-Zr-Ta alloys for orthopedic implan. J. Mech. Behav. Biomed. Mater. 2012, 16, 21-28. [CrossRef]

42. Wei, J.; Sun, H.; Zhang, D.; Gong, L.; Lin, J.; Wen, C. Influence of heat treatments on microstructure and mechanical properties of Ti-26Nb alloy elaborated in situ by laser additive manufacturing with Ti and Nb mixed powder. Materials 2018, 12, 61. [CrossRef] [PubMed]

43. Mehjabeen, A.; Xu, W.; Qiu, D.; Qian, M. Redefining the $\beta$-Phase Stability in Ti-Nb-Zr Alloys for Alloy Design and Microstructural Prediction. Jom 2018, 70, 2254-2259. [CrossRef]

44. Abdel-Hady, M.; Hinoshita, K.; Morinaga, M. General approach to phase stability and elastic properties of $\beta$-type Ti-alloys using electronic parameters. Scr. Mater. 2006, 55, 477-480. [CrossRef]

45. You, L.; Song, X. A study of low Young's modulus Ti-Nb-Zr alloys using d electrons alloy theory. Scr. Mater. 2012, 67, 57-60. [CrossRef]

46. Spreadborough, J.; Christian, J.W. The measurement of the lattice expansions and debye temperatures of titanium and silver by X-ray methods. Proc. Phys. Soc. 1959, 74, 609-615. [CrossRef]

47. Niu, L.; Wang, S.; Chen, C.; Qian, S.F.; Liu, R.; Li, H.; Liao, B.; Zhong, Z.H.; Lu, P.; Wang, M.P.; et al. Mechanical behavior and deformation mechanism of commercial pure titanium foils. Mater. Sci. Eng. A 2017, 707, 435-442. [CrossRef]

48. Barro, Ó.; Arias-González, F.; Lusquiños, F.; Comesaña, R.; Del Val, J.; Riveiro, A.; Badaoui, A.; Gómez-Baño, F.; Pou, J. Improved commercially pure titanium obtained by laser directed energy deposition for dental prosthetic applications. Metals 2021, 11, 70. [CrossRef]

49. Kim, H.Y.; Fu, J.; Tobe, H.; Kim, J., II; Miyazaki, S. Crystal Structure, Transformation Strain, and Superelastic Property of Ti-Nb-Zr and Ti-Nb-Ta Alloys. Shape Mem. Superelasticity 2015, 1, 107-116. [CrossRef]

50. Chang, L.L.; Wang, Y.D.; Ren, Y. In-situ investigation of stress-induced martensitic transformation in Ti-Nb binary alloys with low Young's modulus. Mater. Sci. Eng. A 2016, 651, 442-448. [CrossRef]

51. Ehtemam-Haghighi, S.; Cao, G.; Zhang, L.C. Nanoindentation study of mechanical properties of Ti based alloys with Fe and Ta additions. J. Alloys Compd. 2017, 692, 892-897. [CrossRef]

52. Leyland, A.; Matthews, A. On the significance of the H/E ratio in wear control: A nanocomposite coating approach to optimised tribological behaviour. Wear 2000, 246, 1-11. [CrossRef]

53. Hynowska, A.; Pellicer, E.; Fornell, J.; González, S.; Van Steenberge, N.; Suriñach, S.; Gebert, A.; Calin, M.; Eckert, J.; Baró, M.D.; et al. Nanostructured $\beta$-phase Ti-31.0Fe-9.0Sn and sub- $\mu$ m structured Ti-39.3Nb-13.3Zr-10.7Ta alloys for biomedical applications: Microstructure benefits on the mechanical and corrosion performances. Mater. Sci. Eng. C 2012, 32, $2418-2425$. [CrossRef]

54. Li, P.; Ma, X.; Tong, T.; Wang, Y. Microstructural and mechanical properties of $\beta$-type Ti-Mo-Nb biomedical alloys with low elastic modulus. J. Alloys Compd. 2020, 815, 152412. [CrossRef]

55. Yamamoto, A.; Honma, R.; Sumita, M. Cytotoxicity evaluation of 43 metal salts using murine fibroblasts and osteoblastic cells. J. Biomed. Mater. Res. 1998, 39, 331-340. [CrossRef]

56. Murr, L.E.; Quinones, S.A.; Gaytan, S.M.; Lopez, M.I.; Rodela, A.; Martinez, E.Y.; Hernandez, D.H.; Martinez, E.; Medina, F.; Wicker, R.B. Microstructure and mechanical behavior of Ti-6Al-4V produced by rapid-layer manufacturing, for biomedical applications. J. Mech. Behav. Biomed. Mater. 2009, 2, 20-32. [CrossRef] [PubMed]

57. Karimi, J.; Suryanarayana, C.; Okulov, I.; Prashanth, K.G. Selective laser melting of Ti6Al4V: Effect of laser re-melting. Mater. Sci. Eng. A 2021, 805, 140558. [CrossRef] 